\title{
CLADID CRINOIDS FROM THE LATE KINDERHOOKIAN MEADVILLE SHALE, CUYAHOGA FORMATION OF OHIO
}

\author{
THOMAS W. KAMMER ${ }^{1}$ AND EDGAR W. ROESER ${ }^{2,3}$ \\ ${ }^{1}$ Department of Geology and Geography, West Virginia University, Morgantown, WV 26506-6300, USA, <tkammer@wvu.edu>; ${ }^{2}$ Department of \\ Geology, University of Cincinnati, Cincinnati, OH 45221-0013, USA; and ${ }^{3}$ current address: 2165 Reed Road, Knoxville, MD 1758-1125, USA
}

\begin{abstract}
A total of 17 species of cladid crinoids are documented from the late Kinderhookian Meadville Shale Member of the Cuyahoga Formation of northeastern Ohio, the most diverse assemblage of Kinderhookian-age cladids known in North America. One new genus, six new species, and seven new combinations are reported. New taxa include Cuyahogacrinus lodiensis new genus and species, and the new species Cyathocrinites simplex, Atelestocrinus meszarosi, Goniocrinus sceletus, Aphelecrinus gracilis, and Lebetocrinus ohioensis. New combinations include Logocrinus warreni (Laudon et al., 1952), Histocrinus aegina (Hall, 1863), Paracosmetocrinus richfieldensis (Worthen, 1882), P. corycia (Hall, 1863), Acylocrinus lyriope (Hall, 1863), Linocrinus merope (Hall, 1863), and L. paternus (Hall, 1863). Remaining taxa include Cyathocrinites lamellosus (White, 1863) and Ascetocrinus whitei (Hall, 1861), both of which also occur in the Osagean Burlington Limestone, and the endemic species Cosmetocrinus crineus (Hall, 1863) and Pachylocrinus subtortuosus (Hall, 1863).

Collectively, the cosmopolitan genera and species of cladids show a greater overall affinity with Osagean cladid faunas than with other Kinderhookian cladid faunas. However, this is true for other Kinderhookian cladid faunas as well that individually have more taxa in common with Osagean faunas than other Kinderhookian faunas. This suggests a greater degree of endemism and local speciation during the Kinderhookian as a prelude to the rapid radiation of cladids, and other crinoids, during the Osagean.
\end{abstract}

\section{INTRODUCTION}

$\mathrm{C}$ RINOIDS FROM the Lower Mississippian Meadville Shale at Richfield, Summit County, Ohio were first noted by Hall (1863) and later fully described and illustrated by Hall and Whitfield (1875). Aside from a few reports of isolated species, this is the only Kinderhookian crinoid fauna known from the eastern United States (Bassler and Moodey, 1943; Webster, 2003). The fauna at Richfield was not studied again until Roeser recollected the original site for his Master's thesis work at the University of Cincinnati (Roeser, 1986). The purpose of this paper is to provide a modern interpretation of the cladid crinoids from the Meadville Shale by updating Roeser's previous work and combining it with study of additional crinoids housed in the Cleveland Museum of Natural History. The camerates and disparids are treated in a companion paper by Ausich and Roeser (2012). Full knowledge of the Kinderhookian Meadville Shale crinoids, in combination with knowledge of other Kinderhookian faunas, is necessary to better understand the preliminary stages of the explosive radiation in the Osagean that led to the "Age of Crinoids" (Kammer and Ausich, 2006). More specifically, the Meadville Shale crinoids lived in a shallow marine deltaic setting and were precursors of the extremely diverse and abundant crinoid faunas of the late Osagean Borden delta of Indiana and Kentucky (Ausich et al., 1979; Ausich, 1980; Kammer and Ausich, 1987). Thus, a better understanding of the Meadville Shale crinoids will help shed light on future studies of the community evolution of Early Mississippian crinoids in clastic depositional environments.

\section{GEOGRAPHIC AND STRATIGRAPHIC \\ OCCURRENCE OF THE CRINOIDS}

Hall and Whitfield (1875) described the "Crinoidea of the Waverly Group." The Waverly Group, once thought to be synonymous with the Lower Mississippian (Hyde, 1953), is generally no longer used because it includes the Late Devonian Bedford Shale and Berea Sandstone, which together comprise a separate depositional sequence (Pashin and Ettensohn, 1995), as well as the Mississippian Cuyahoga and Logan formations, which represent two additional depositional sequences (Matchen and Kammer, 2006). The crinoids occur in the Meadville Shale Member of the Cuyahoga Formation (Table 1), which is also known for the abundant ophiuroid Strataster ohioensis Kesling and LeVasseur (1971) at North Royalton, $10 \mathrm{~km}$ northwest of the Richfield site.

With assistance from the amateur paleontologist Gary Meszaros, Roeser (1986) was able to locate what was thought to be the same horizon in the upper part of the Meadville Shale in Richfield Township where James Hall obtained crinoids. Roeser's Richfield site is located along a creek, $0.6 \mathrm{~km}$ southeast of the junction of Brush Road and Humphrey Road, in the northern half of Richfield Township, Summit County, Ohio, at Lat. N 41 ${ }^{\circ} 14^{\prime} 52.6^{\prime \prime}$, Long. W 81 ${ }^{\circ} 38^{\prime} 22.6^{\prime \prime}$ (Google Earth). Approximately $19 \mathrm{~m}$ of interbedded shale and siltstone are exposed, although neither the base nor top of the $70 \mathrm{~m}$ thick Meadville Shale is exposed. The crinoids were all collected from a single thin bed of lensoidal siltstone in shale approximately $15 \mathrm{~m}$ above the base of the exposed interval (Unit 31 of Roeser, 1986). Previously, during the 1970s, Gary Meszaros was collecting and preparing crinoids from the Meadville Shale at Lodi, in Medina County, Ohio. In 1982 he donated his collection of crinoids from Lodi to the Cleveland Museum of Natural History. Meszaros' Lodi site is located along a creek at the southeast corner of the junctions of State Route 224 and County Highway 28, $5.5 \mathrm{~km}$ west of the center of Lodi, Medina County, Ohio, at Lat. N 41 $01^{\prime} 26^{\prime \prime}$, Long. W 82 $04^{\prime} 33^{\prime \prime}$ (Google Earth). The crinoids also occurred in thin siltstone beds. The exact stratigraphic position within the Meadville Shale is unknown.

The excellent preservation of complete crinoid crowns at both localities, and their occurrence in graded, lensoidal siltstone beds within shale, suggests rapid burial of living animals, probably as tempestite deposits on a shallow marine shelf (Roeser, 1986; Ausich et al., 1999). Common plant debris 
TABLE 1-Members of the Lower Mississippian Cuyahoga Formation in northern Ohio and the Logan Formation in central Ohio, and typical thicknesses (Szmuc, 1970; Coogan et al., 1981; Matchen and Kammer, 2006)

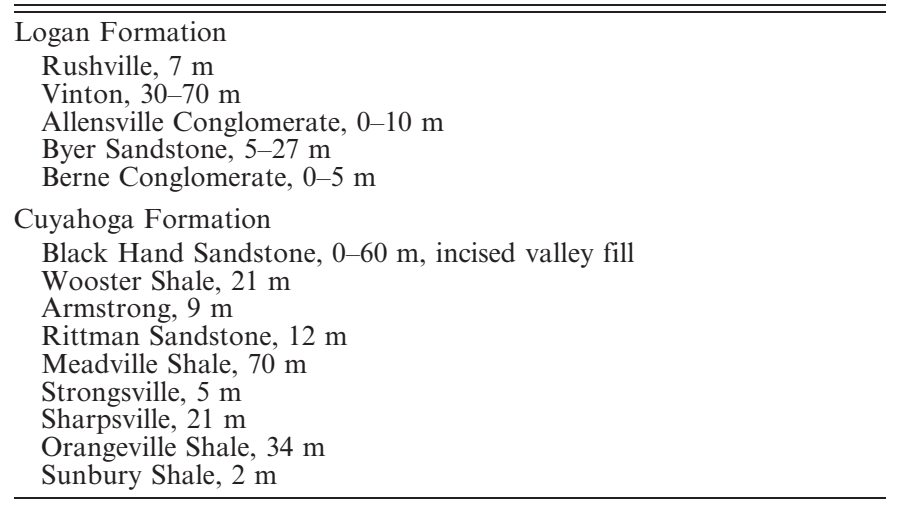

preserved with the crinoids suggests relative proximity to a shoreline. The crinoids are associated with other marine invertebrates including brachiopods, bryozoans, gastropods, bivalves, and glass sponges.

The Cuyahoga Formation in northern Ohio is divided into as many as nine members (Table 1), with a total maximum thickness of $189 \mathrm{~m}$ (Szmuc, 1970). These members are defined by local lithologic changes between varying proportions of shale, siltstone, and sandstone (Szmuc, 1970; Coogan et al., 1981), with finer-grained units such as the Sunbury, Orangeville, and Meadville shales, or coarser-grained units such as the Rittman and Black Hand sandstones. All of the members are marine in origin, except for the braided river deposits of the Black Hand Sandstone that fill an incised valley in the underlying marine units of the Cuyahoga Formation (Matchen and Kammer, 2006). The Meadville Shale, ranging from $64-76 \mathrm{~m}$ in thickness, is the most fossiliferous member of the Cuyahoga Formation in northern Ohio containing brachiopods, bivalves, gastropods, nautiloids, bryozoans, trilobites, and crinoids (Szmuc, 1970).

The overlying Logan Formation is best developed in central Ohio, being mostly absent in northern Ohio. Generally it is coarser-grained than the Cuyahoga Formation and consists of shallow marine siltstones and sandstones of the Byer Sandstone and Vinton members, and the thin sheet conglomerates of the Berne and Allensville members (Table 1). In central Ohio, the Logan Formation is separated from the Cuyahoga Formation by a sequence boundary at the base of the Berne Conglomerate Member (Matchen and Kammer, 2006, fig. 12).
AGE RELATIONSHIPS

Age of Meadville Shale.-The Strongsville Member, directly beneath the Meadville Shale (Table 1), contains conodonts of the Siphonodella quadruplicata-S. crenulata Zone of Collinson et al. (1971) (Lahola, 1974), which correlates it to the upper part of the Hannibal Formation, or middle Kinderhookian, of the Mississippi Valley (Collinson et al., 1971). Szmuc (1957), on the basis of brachiopods, assigned the Meadville Shale to the Kinderhookian. The overlying Wooster Shale Member near the top of the Cuyahoga Formation (Table 1) contains a brachiopod fauna that both Szmuc (1957) and Rodriquez (1961) indicated was either latest Kinderhookian or earliest Osagean in age. Matchen and Kammer (2006) and Kammer and Matchen (2008) presented evidence that the youngest member of the Cuyahoga Formation in north-central Ohio, the Black Hand Sandstone (Table 1), is an incised valley fill deposited during a eustatic fall in sea level at the Kinderhookian-Osagean boundary. Brezinski (2009), on the basis of trilobites, including some from the Meadville Member, assigned the Cuyahoga Formation in northern Ohio to the Kinderhookian, and the overlying Logan to the Osagean. The Logan Formation is undoubtedly early Osagean in age based on the occurrence of the ammonoid Muensteroceras from the Byer Member (Table 1) at Newark, Licking County (Hyde, 1953, p. 340), approximately $100 \mathrm{~km}$ south of Medina County. Muensteroceras is restricted to the early Osagean (Gordon, 1986; Kullman et al., 1990). The Rushville Member at the top of the Logan Formation contains conodonts of the Doliognathus latus Subzone of the Bactrognathus-Pseudopolygnathus multistriatus Zone (Thompson et al., 1971), which correlates it to the upper part of the lower Burlington Limestone, or middle-early Osagean age (Collinson et al., 1971, fig. 6). Based on the combined data above, the Meadville Shale Member of the Cuyahoga Formation in northern Ohio is judged to be late Kinderhookian in age (time unit 2 of Ausich and Kammer, 2008, table 3).

Comparison with other faunas. - With the late Kinderhookian age of the Meadville Shale determined independently from other faunal groups and stratigraphic relationships, the chronological significance of the crinoid fauna can be evaluated. Of the 14 genera, only 8 have previously been reported from the Kinderhookian (Table 2), and only one of these, Paracosmetocrinus, is restricted to the Kinderhookian. One genus, Logocrinus, has its range extended upward from the Devonian (Frasnian) (Table 2), and four genera have their ranges extended downward from the Osagean, Acylocrinus, Ascetocrinus, Atelestocrinus, and Lebetocrinus. Of the 14 genera, $11(79 \%)$ also occur in the Osagean.

TABLE 2-Seriation of previously reported ranges (Webster, 2003) of crinoid genera found in the Meadville Shale. Cuyahogacrinus n. gen. is excluded because it is known only from the Meadville Shale.

\begin{tabular}{lcccc}
\hline \hline & Devonian & Kinderhookian & Osagean & Meramecian \\
\hline Logocrinus & $\mathrm{X}$ & $\mathrm{X}$ & $\mathrm{X}$ & $\mathrm{X}$ \\
Cyathocrinites & $\mathrm{X}$ & $\mathrm{X}$ & $\mathrm{X}$ \\
Pachylocrinus & $\mathrm{X}$ & $\mathrm{X}$ & $\mathrm{X}$ & $\mathrm{X}$ \\
Paracosmetocrinus & & $\mathrm{X}$ & $\mathrm{X}$ \\
Goniocrinus & & $\mathrm{X}$ & $\mathrm{X}$ & $\mathrm{X}$ \\
Histocrinus & & $\mathrm{X}$ & $\mathrm{X}$ \\
Aphelecrinus & $\mathrm{X}$ & $\mathrm{X}$ & $\mathrm{X}$ \\
Cosmetocrinus & & $\mathrm{X}$ & $\mathrm{X}$ \\
Linocrinus & & $\mathrm{X}$ & $\mathrm{X}$ \\
Acylocrinus & & $\mathrm{X}$ & \\
Ascetocrinus & & $\mathrm{X}$ & \\
Atelestocrinus & & & \\
Lebetocrinus & & & \\
\hline
\end{tabular}


TABLE 3-Seriation of ranges for cosmopolitan crinoid species found in the Meadville Shale.

\begin{tabular}{lcc}
\hline \hline & Kinderhookian & Osagean \\
\hline Logocrinus warreni & $\mathrm{X}$ & \\
Histocrinus aegina & $\mathrm{X}$ & $\mathrm{X}$ \\
Cyathocrinites lamellosus & & $\mathrm{X}$ \\
Ascetocrinus whitei & & \\
\hline
\end{tabular}

Of the 17 species, 13 are endemic to the Meadville Shale and four are cosmopolitan (Table 3), occurring in other formations. Logocrinus warreni (Laudon, Parks, and Spreng, 1952) also occurs in the late Kinderhookian-early Osagean Banff Formation of Alberta, and Histocrinus aegina (Hall, 1863) occurs in the Kinderhookian Maynes Creek Formation at Legrand, Iowa (as the synonym Decadocrinus baumgardneri Laudon and Beane, 1937). Both Cyathocrinites lamellosus (White, 1863) and Ascetocrinus whitei (Hall, 1861) also occur in the Osagean Burlington Limestone.

The blend of Kinderhookian and Osagean taxa might suggest an age assignment near the Kinderhookian-Osagean boundary, but other biostratigraphic data presented above constrain the Meadville Shale to the late Kinderhookian. Osagean crinoid faunas are much more numerous and diverse (Kammer et al., 1998) than Kinderhookian faunas (Gahn and Baumiller, 2004), so improved documentation of Kinderhookian faunas is more likely to create range extensions downward from the Osagean than vice versa.

A further argument for the Kinderhookian age is a negative one. The primitive cladid Barycrinus is very common in the Osagean with eight species (Kammer and Ausich, 1996; Gahn and Kammer, 2002) and is usually present at all relatively diverse Osagean sites (Kammer et al., 1998). Thus, its absence from all Kinderhookian units, including the Meadville Shale, unites them as distinct from the Osagean.

The high genus-level similarity between the Meadville Shale cladids and Osagean faunas (11 of 14 , or 79 percent) can be seen in other Kinderhookian faunas as well where a large majority of their genera also occur in the Osagean (Table 4), the mean being 78 percent. Similarity is based on the number of shared genera divided by the total genera of the smaller fauna. Oddly, similarities between Kinderhookian faunas are much lower. The Meadville Shale shares only $57 \%(\mathrm{n}=8)$ of its genera with other Kinderhookian faunas, which is higher than the mean similarity of 39 percent between the other Kinderhookian faunas listed in Table 4. Why are Kinderhookian faunas less similar to each other than to Osagean faunas in general? This may simply be a statistical artifact resulting from comparison of small samples (individual Kinderhookian faunas) to a set of more inclusive pooled samples (all Osagean faunas). Still, the Meadville Shale's 57 percent similarity with the pooled other Kinderhookian faunas is about three-fourths of its 79 percent similarity with the overall Osagean. But this too may be an artifact from the downward range extension of the five Osagean genera found in the Meadville Shale.

However, based on the low similarities between Kinderhookian faunas (Table 4), it does appear these faunas had low numbers of cosmopolitan taxa and a high degree of endemism. This would suggest high rates of local speciation as a prelude to the rapid radiation of Osagean crinoids (Kammer and Ausich, 2006; Sallan et al., 2011). For example, the Meadville Shale with 14 genera has the highest number of cladids in a Kinderhookian fauna, out of the total of 34 for the Kinderhookian across North America (Appendix). By comparison, the early Osagean Burlington Limestone of Iowa has 34 cladid genera (Gahn and Kammer, 2002; Kammer and Gahn, 2003; Kammer, 2008), out of a total of 59 North American Osagean cladid genera (Kammer and Ausich, unpublished), documenting a near doubling of cladid diversity from the Kinderhookian to the Osagean.

\section{SYSTEMATIC PALEONTOLOGY}

Classification of cladid crinoids follows Moore et al. (1978), with the following exception. The Order Poteriocrinida as defined by Moore et al. (1978) is generally thought to be a polyphyletic grouping composed of several pinnulate taxa derived from the Order Dendrocrinida. Instead, we follow McIntosh (2001) in placing pinnulate (advanced) cladid crinoids in the Dendrocrinida. We also recognize that family-level taxonomy is in need of modern phylogenetic analysis, which is beyond the scope of the present study. Diagnoses are provided for all genera and species, with full descriptions only for new taxa.

Terminology follows Ubaghs (1978). Examined material is housed in the following museums: CMCIP, Cincinnati Museum Center; CMNH, Cleveland Museum of Natural History; NYSM, New York State Museum; SUI, University of Iowa; USNM, U.S. National Museum of Natural History. See Webster (2003) for complete synonymy lists.

Class CRINOIDEA Miller, 1821

Subclass ClADIDA Moore and Laudon, 1943

Order CYATHOCRININA Bather, 1899

Superfamily CYATHOCRINITOIDEA Bassler, 1938

Family CYATHOCRINIDAE Bassler, 1938

Genus CyATHOCRINITES Miller, 1821

Type species.-Cyathocrinites planus Miller, 1821; by subsequent designation (Wachsmuth and Springer, 1880).

Diagnosis.-Crown tall, subcylindrical to pear shaped; aboral cup bowl shaped, low to medium height, base convex to concave, plates smooth or ornamented with nodes, ridges, and or pits; infrabasals may be up to one third size of basals; basals as large or larger than radials; radials equidimensional; radial facet nearly angustary, horseshoe shaped; only one anal plate, anal X, in cup; anal sac approximately half the height of the arms, composed of thick, interlocking polygonal plates; primibrachial number variable, ranging from one to six; arm

TABLE 4-Similarity matrix of shared cladid genera (number of shared genera divided by total genera of smaller fauna) between Kinderhookian faunas and the Osagean; see Appendix for faunas. The Banff Formation of Alberta spans the late Kinderhookian-early Osagean time interval (Carter, 1987).

The Maynes Creek Formation of Iowa equals Hampton Formation of older literature. The Lodgepole Formation is in Montana; the Henderson Canyon Formation is in Utah andWyoming (Webster, 1997); and the Gilmore City Formation is in Iowa.

\begin{tabular}{|c|c|c|c|c|c|c|}
\hline & $\begin{array}{l}\text { Meadville Shale } \\
\text { (14 genera) }\end{array}$ & $\begin{array}{c}\text { Banff } \\
\text { Fm (12) }\end{array}$ & $\begin{array}{c}\text { Maynes Creek } \\
\text { Fm (12) }\end{array}$ & $\begin{array}{l}\text { Lodgepole } \\
\text { Fm (10) }\end{array}$ & $\begin{array}{c}\text { Henderson Canyon } \\
\text { Fm (10) }\end{array}$ & $\begin{array}{l}\text { Gilmore City } \\
\text { Fm (8) }\end{array}$ \\
\hline Banff Fm. & $33 \%$ & & & & & \\
\hline Maynes Creek Fm. & $33 \%$ & $33 \%$ & & & & \\
\hline Lodgepole Fm. & $40 \%$ & $70 \%$ & $50 \%$ & & & \\
\hline Henderson Canyon Fm. & $33 \%$ & $33 \%$ & $40 \%$ & $50 \%$ & & \\
\hline Gilmore City Fm. & $38 \%$ & $13 \%$ & $50 \%$ & $38 \%$ & $10 \%$ & \\
\hline Osagean & $79 \%$ & $83 \%$ & $100 \%$ & $70 \%$ & $50 \%$ & $88 \%$ \\
\hline
\end{tabular}


branching complex, uneven isotomous or heterotomous; arms become progressively smaller above each axillary plate; column circular, heteromorphic (Kammer and Gahn, 2003).

Discussion.-There are relatively few reports of Cyathocrinites from the Kinderhookian, which makes these Meadville Shale specimens significant. Miller and Gurley (1895) described $C$. chouteauensis from the Chouteau Limestone of Missouri. Laudon et al. (1952, p. 547, pl. 65, fig. 8) illustrated a Cyathocrinites sp. from the Banff Formation of Alberta, probably a $C$. lamellosus (White, 1863), which we report from the Meadville Shale. Laudon et al. (1952, p. 547, pl. 65, figs. $3-$ 7) also illustrated other specimens of Cyathocrinites sp. from the Banff, which appear to be $C$. iowensis (Owen and Shumard, 1850). Laudon and Severson (1953, pl. 51, figs. 13, 14, USNM 123146) illustrated a Cyathocrinites sp. from the Lodgepole Formation of Montana, which also appears to be $C$. iowensis. These reports would extend the range of $C$. iowensis into the Kinderhookian (Kammer and Ausich, 1996; Kammer and Gahn, 2003). No specimens assignable to $C$. iowensis were found in the Meadville Shale.

\section{CYATHOCRINITES LAMELLOSUS (White, 1863)} Figures 1.1-1.4, 2.1, 2.2

Cyathocrinus lamellosus WHITE, 1863, p. 504.

Cyathocrinites lamellosus (WHITE, 1863). BASSLER AND MoOdeY, 1943, p. 392; KAMMER AND GAHN, 2003, p. 123 , fig. 2.2-2.4.

Cyathocrinites exertus ROESER, 1986, p. 154, nomen nudum.

Diagnosis.-A species of Cyathocrinites with infrabasal circlet flat to slightly invaginated, swollen or tumid basals; thin cup plates with sculpture consisting of nodes with radiating ridges; brachials longer than wide with distinct keels; arm branching at axillaries more U-shaped than V-shaped.

Material examined-CMCIP 46156 (Fig. 1.1), 46157 (Figs. 1.2, 2.1) and 46158 (Figs. 1.4, 2.2) from Richfield and CMNH 5804 and 5597 (Fig. 1.3) from Lodi.

Occurrence.-The Meadville Shale Member of the Cuyahoga Formation, Richfield and Lodi, Ohio; and the upper part of the Burlington Limestone, Burlington, Iowa (Kammer and Gahn, 2003).

Discussion.- See Kammer and Gahn (2003, p. 123) for a description of this species. Specimens of C. lamellosus from the Meadville Shale appear to be conspecific with those from the Burlington Limestone illustrated by Kammer and Gahn (2003, fig. 2.2-2.4). The only possible difference is the 2 to 3 primibrachials in the former versus 2 to 4 in the latter, but the number of primibrachials is variable within species of this genus, as noted above. The brachial keels distinctive of this species are visible on arms that have not been abraded during weathering or preparation. Identification of this species in the Meadville Shale extends its range from the early Osagean downward to the late Kinderhookian.

A specimen from the Banff Formation illustrated by Laudon et al. (1952, p. 547, pl. 65, fig. 8) as Cyathocrinites sp. (GSC 9906 and 9907) also appears to be C. lamellosus.

\section{CYATHOCRINITES SIMPLEX new species} Figure 1.5-1.7

Cyathocrinites simplex ROESER, 1986, p. 164, nomen nudum.

Diagnosis.-A species of Cyathocrinites with visible infrabasals on a subconical cup, with thin plates lacking ornamentation; smooth elongate brachials.

Description.-Crown tall, subcylindrical to distally expanded. Aboral cup bowl shaped, medium height, plates thin, smooth and lacking ornamentation; infrabasals small; basals hexagonal, slightly larger than radials; radials wider than high, facets angustary (Table 5). Only one anal plate, anal X, in cup; anal sac present, but poorly known. Three to four primibrachials on each ray; arm branching complex, heterotomous, as many as three bifurcations in line on a single ray; arms become progressively smaller above each axillary plate. Arm branching at axillaries tends to form more of a U-shape than a V-shape. Brachials elongate, smooth. Column circular, homeomorphic.

Etymology.-Simplex for the smooth, unornamented plates.

Material examined.-The holotype CMCIP 46159 (Fig. 1.5) and 46160 (missing), from Richfield, Ohio; and the two paratypes CMNH 5718-20 (Fig. 1.7) and CMNH 5956-10 (Fig. 1.6), from Lodi, Ohio.

Occurrence.-The Meadville Shale Member of the Cuyahoga Formation, Richfield and Lodi, Ohio.

Discussion.-Cyathocrinites simplex new species is similar to C. chouteauensis (Miller and Gurley, 1895) (Fig. 1.8) from the Chouteau Limestone of Sedalia, Missouri (holotype, CMCIP 4006), the only other named species of the genus from the Kinderhookian (Webster, 2003). The holotype, and only specimen, of C. chouteauensis (Miller and Gurley, 1895, p. 68, pl. 4, fig. 16; Peck and Keyte, 1938, pl. 2, fig. 12; Fig. 1.8) has a cup essentially identical to $C$. simplex, but the arms are not preserved with only a few disarticulated, but elongate, brachials preserved. The additional specimen illustrated by Miller and Gurley (1896, pl. 2, fig. 24) and Peck and Keyte (1938, pl. 2, fig. 13 ) is not a Cyathocrinites and may be a Hypselocrinus. Thus, the well preserved Meadville Shale specimens with complete arms cannot be assigned with certainty to this species and are instead assigned to $C$. simplex new species. If specimens of $C$. chouteauensis with complete arms similar to $C$. simplex were to be found in the future from the Chouteau Limestone, then C. simplex might have to be placed in synonymy.

Cyathocrinus? marshallensis (Worthen, 1882, 1883, pl. 30., fig. 4), from the Kinderhookian Maynes Creek Formation, has a nondiagnostic illustration, but shows plenary, rather than angustary, radial facets, thus indicating a different genus, probably an advanced cladid. Inspection of the holotype (University of Illinois, UIX-833) confirmed the plenary facets, which along with three primibrachials and a single anal plate suggest this species is allied with Armenocrinus, but the preservation is too poor to make a confident assignment.

Cyathocrinites simplex new species differs from all known Osagean species of Cyathocrinites (Kammer and Ausich, 1996; Kammer and Gahn, 2003) in having a medium height, subconical cup, with thin, smooth plates, and smooth, elongate brachials. The Meadville Shale specimens share all these characters and are clearly conspecific with the Chouteau Limestone holotype, which is the only specimen known from that formation.

Order DENDROCRININA Bather, 1899

Superfamily MASTIGOCRINOIDEA Jaekel, 1918 Family MASTIGOCRINIDAE Jaekel, 1918

Genus ATElestocrinus Wachsmuth and Springer, 1886

Type species.-Atelestocrinus delicatus Wachsmuth and Springer, 1886; by subsequent designation (Miller, 1889).

Diagnosis.-Crown tall, slender; aboral cup extremely high; plates thin, smooth; infrabasals, basals, or radials may be greatly elongated; infrabasals constricted at the top; radial facet peneplenary, crescentic; A ray armless; zero or three anals in the cup; anal sac unknown; two to five primibrachials; arm branching simple with ramules arising on alternate sides of every second secundibrachial, column pentagonal. 

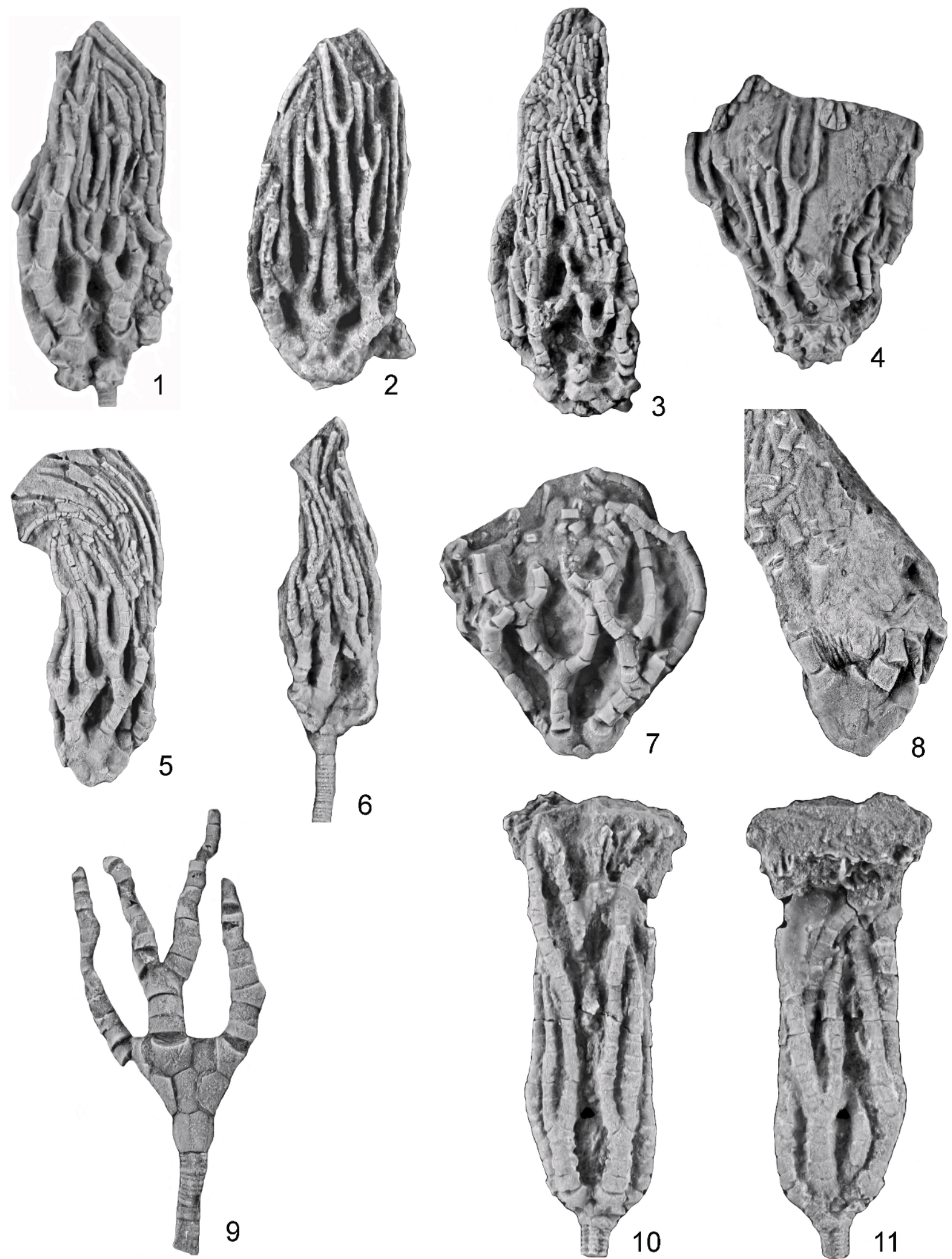

6
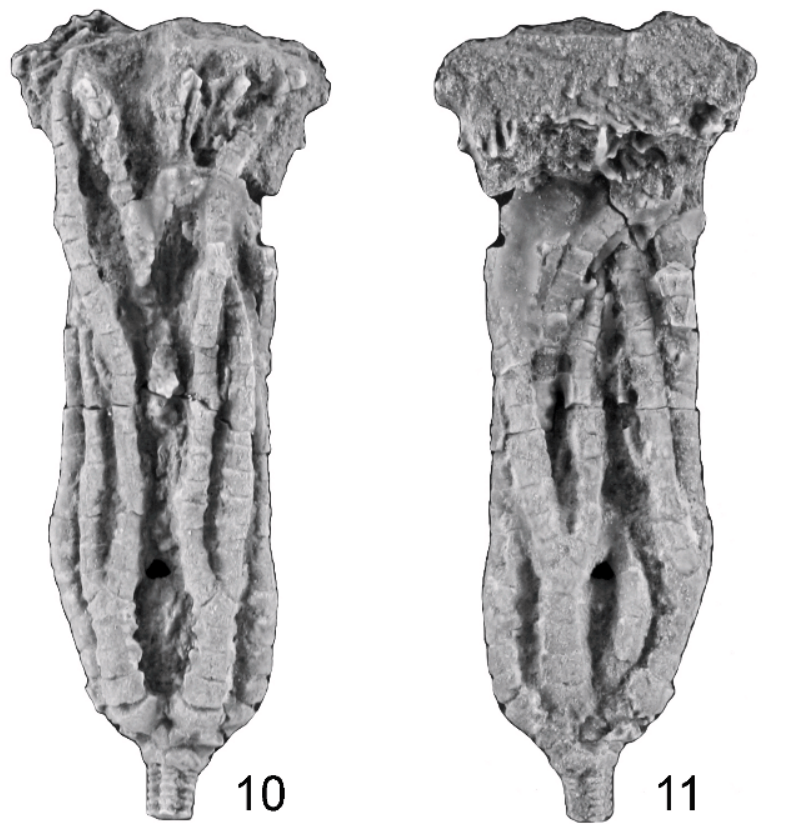

Figure 1-1-4, Cyathocrinites lamellosus (White, 1863): 1, D-E ray view, CMCIP 46156, $\times 3.0 ; 2$, D-E ray view, CMCIP 46157, $\times 2.0 ; 3$, anterior view (pits from preparation), CMNH 5597, $\times 2.0 ; 4$, anterior view, CMCIP 46158, $\times 2.0 ; 5-7$, Cyathocrinites simplex n. sp.: 5, D-E ray view, holotype, CMCIP $46159, \times 2.0 ; 6$, posterior view, paratype, CMNH 5956-10, $\times 2.0 ; 7$, anterior view, paratype, CMNH 5718-20, $\times 2.0 ; 8$, Cyathocrinites chouteauensis $($ Miller and Gurley, 1895), A-B rays view, holotype, CMCIP 4006, Chouteau Limestone, Sedalia, Missouri, $\times 1.5 ; 9$. Atelestocrinus meszarosi n. sp., posterior view, holotype, CMNH 5937, ×2.0; 10, 11, Goniocrinus sceletus n. sp., anterior and posterior views, holotype, CMCIP 46161, ×3.0. 

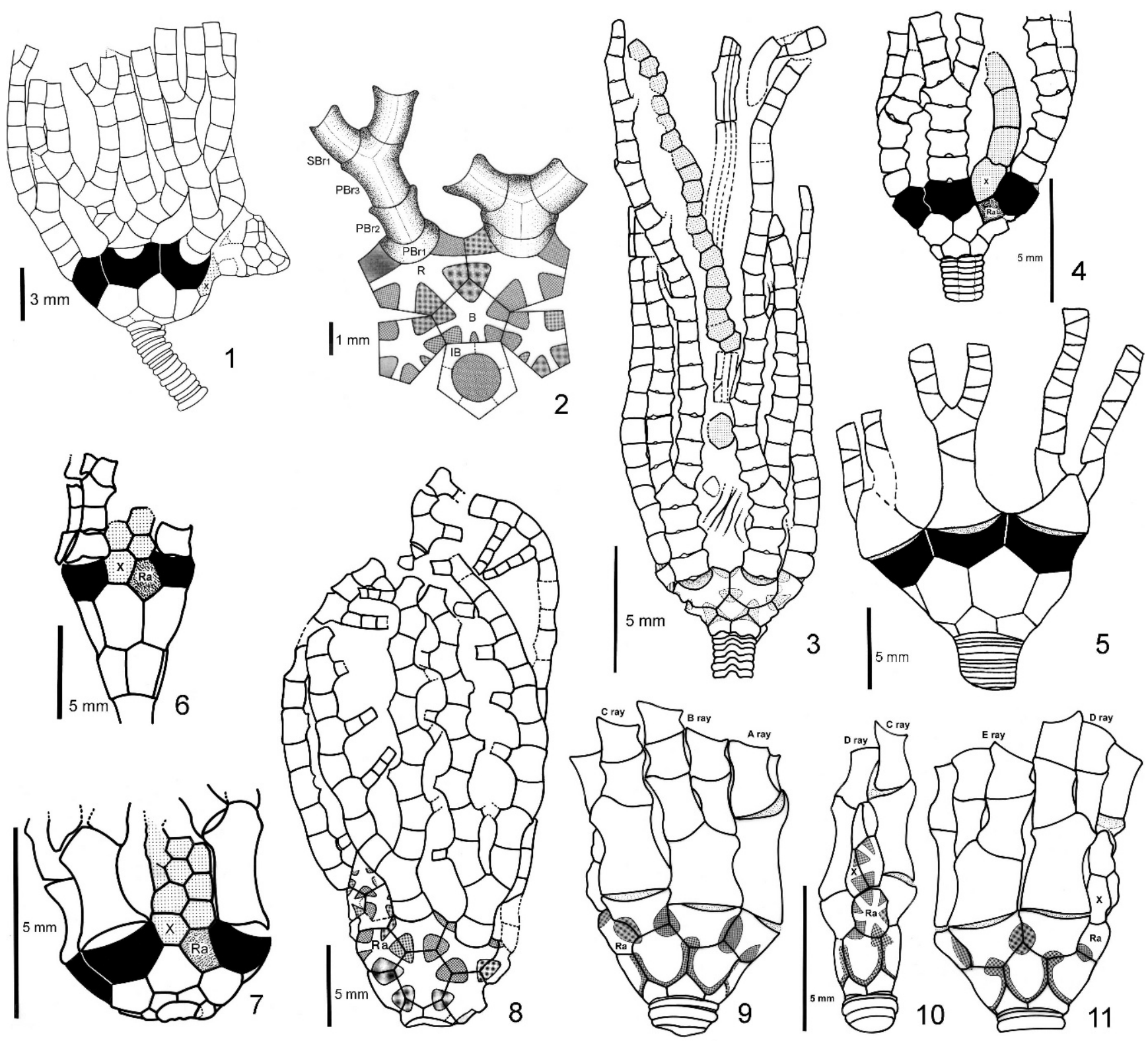

FIGURE 2-Plate diagrams; radials in black; $\mathrm{Ra}=$ radianal plate; $\mathrm{X}=$ anal $\mathrm{X}$ plate. 1, 2, Cyathocrinites lamellosus (White, 1863): 1, centered on $\mathrm{E}$ ray, CMCIP 46157; 2, ray position uncertain, CMCIP 46158; 3, 4, Goniocrinus sceletus n. sp., holotype, CMCIP 46161: 3, A-B interray view; 4, posterior view; 5, Cuyahogacrinus lodiensis n. gen. n. sp., holotype, centered on A ray, CMNH 5598; 6, Logocrinus warreni (Laudon et al., 1952), posterior view, CMCIP 46164; 7, Paracosmetocrinus richfieldensis (Worthen, 1882), posterior view, CMCIP 46177; 8, Histocrinus aegina (Hall, 1863), centered on C ray, CMCIP 46168; 9-11, Ascetocrinus whitei (Hall, 1861), B ray, posterior, and D-E ray views, CMCIP 46173.

Discussion.-The four previously recognized species of Atelestocrinus are A. robustus Wachsmuth and Springer (1885), A. delicatus, A. indianensis Ausich and Lane (1982), and A. kentuckyensis Lee et al. (2005). Atelestocrinus delicatus, from the early Osagean, has greatly elongated infrabasals, and basals and radials that are smaller but nearly equal in height. Atelestocrinus robustus, from the middle to late Osagean, has greatly elongated basals, with short infrabasals and mediumheight radials. Atelestocrinus kentuckyensis, from the middle

TABLE 5-Measurements, in mm, of holotype of Cyathocrinites simplex n. sp.

\begin{tabular}{|c|c|c|c|c|c|c|c|c|}
\hline \multirow{2}{*}{$\begin{array}{c}\text { Crown } \\
\mathrm{H}\end{array}$} & \multicolumn{2}{|c|}{ Cup } & \multicolumn{2}{|c|}{ Infrabasal (D) } & \multicolumn{2}{|c|}{ Basal (D-E) } & \multicolumn{2}{|c|}{ Radial (D) } \\
\hline & $\mathrm{H}$ & W & $\mathrm{H}$ & $\mathrm{W}$ & $\mathrm{H}$ & W & $\mathrm{H}$ & W \\
\hline 31.0 & 5.4 & $2.4-6.5$ & 0.9 & 1.2 & 2.4 & 2.2 & 1.6 & 2.6 \\
\hline
\end{tabular}

Osagean, has greatly elongated radials with the infrabasals and basals unknown; there are two tegmen plates sitting above the teardrop-shaped A radial in the cup. Atelestocrinus indianensis, from the late Osagean, has greatly elongated radials with the infrabasals and basals unknown; there are no tegmen plates above the A radial in the cup. See Ausich and Lane (1982, p. 1350), Kammer and Gahn (2003, p. 122), and Lee et al. (2005, p. 349) for more on this genus.

\section{Atelestocrinus meszarosi new species} Figure 1.9

Diagnosis.-A species of Atelestocrinus with both infrabasals and basals elongated, which are nearly equal in height; radials shorter.

Description.-Crown simple, four arms total visible on the three exposed rays. Cup shape steep-sided cone with concave 
TABLE 6-Measurements, in mm, of holotype of Atelestocrinus meszarosi n. sp.

\begin{tabular}{|c|c|c|c|c|c|c|c|c|c|c|}
\hline \multirow{2}{*}{$\begin{array}{c}\text { Crown } \\
\mathrm{H}\end{array}$} & \multicolumn{2}{|c|}{ Cup } & \multicolumn{2}{|c|}{ Infrabasal } & \multicolumn{2}{|c|}{ Basal (E-A) } & \multicolumn{2}{|c|}{ Radial (A) } & \multicolumn{2}{|c|}{ Radial (B) } \\
\hline & $\mathrm{H}$ & $\mathrm{W}$ & $\mathrm{H}$ & $\mathrm{W}$ & $\mathrm{H}$ & $\mathrm{W}$ & $\mathrm{H}$ & $\mathrm{W}$ & $\mathrm{H}$ & $\mathrm{W}$ \\
\hline$>30.0$ & 10.2 & $2.9-10.0$ & 4.0 & 2.0 & 4.2 & 2.0 & 3.0 & 2.3 & 3.0 & 4.2 \\
\hline
\end{tabular}

sides; plates thin, smooth, lacking ornamentation; infrabasals elongate, twice as high as wide; basals elongate, twice as high as wide; radials wider than high, A-radial armless with straight edge along top, $\mathrm{B}$ and $\mathrm{E}$ radials with crescentic, peneplenary facets that contain a fulcral ridge (Table 6). Anal plates unknown as posterior not exposed. Arms branch once on primibrachial three on the exposed E, A, and B rays; higher branchings not observed, 7 to 10 secundibrachials exposed on the arms; ramules not preserved. Column flattened, may have been subpentagonal, at least at the proxistele; heteromorphic with nodals and internodals.

Etymology.-Named in honor of Gary Meszaros who found, prepared, and donated hundreds of crinoids from Lodi, Ohio, to the Cleveland Museum of Natural History, including the holotype of this species.

Material examined.-The holotype, and only known specimen, CMNH 005937 (Fig. 1.9).

Occurrence.-The Meadville Shale Member of the Cuyahoga Formation at Lodi, Ohio.

Discussion.-The various species of Atelestocrinus are readily separated by which circlet of cup plates is elongated. However, A. meszarosi is unique in having both the infrabasals and basals equally elongate. The late Kinderhookian age makes this the oldest known species in the genus and perhaps ancestral to the later species. The next younger species, $A$. delicatus, had only elongate basals, whereas the next youngest, $A$. robustus, had only elongate infrabasals. Both of these younger species appear to be variations on $A$. meszarosi n. sp. by changing the length of either the infrabasals or basals. The two youngest species, A. indianensis and A. kentuckyensis, experimented with longer radials.

\section{Genus Goniocrinus Miller and Gurley, 1890}

Type species.-Goniocrinus sculptilis Miller and Gurley, 1890 , by original designation.

Diagnosis.-A quadrangular anal X plate, sitting above the small radianal, supports a series of anal plates that resemble an atomous arm; brachial and anal plates with distinct flanges along outer edges; arms ramulate.

\section{GONIOCRINUS SCELETUS new species \\ Figures 1.10, 1.11, 2.3, 2.4}

Goniocrinus sceletus RoESER, 1986, p. 171, nomen nudum.

Diagnosis.-A species of Goniocrinus with the radials much larger than the basals and infrabasals, forming an upwardly flaring, low conical cup; deep apical pits at the corners of the cup plates.

Description.-Crown tall, cylindrical (Table 7). Cup small, low cone with upward flaring sides; plates medium thickness; deep apical pits at plate corners, which give plates a corrugated texture; infrabasals small, vertical, visible in side view; basals small, but slightly larger than infrabasals; radials largest plates in cup with crescentic, angustary facets that are declivate and have a gape between radials and first primibrachials. Anal plates two, including a quadrangular radianal supporting a large anal $\mathrm{X}$ at the base of an anal tube consisting of a vertical row of rectangular plates that resemble an arm.
Arms ten, branching once on primibrachial four in A-D rays and on primibrachial three in $\mathrm{E}$ ray; ramules present on secundibrachials, but poorly preserved; brachial plates flared with flanges at the outer, distal edges as is common in the genus, best developed on primibrachials. Column pentalobate, heteromorphic with nodals and internodals.

Etymology.-Sceletus, or skeleton.

Material examined.-The holotype, and only known specimen, CMCIP 46161 (Fig. 1.10, 1.11).

Occurrence.-The Meadville Shale Member of the Cuyahoga Formation at Richfield, Ohio.

Discussion.-There are five other species of Goniocrinus. Kinderhookian species include $G$. angulatus Laudon et al. (1952) from the Banff Formation, which has infrabasals and radials larger than the basals, which are not constricted; $G$. sculptilis from the Maynes Creek Formation, which has basals twice the size of infrabasals; and G. maximus Laudon (1933) from the Gilmore City Limestone, which is clearly a Goniocrinus with its quadrangular anal X supporting a vertical row of anal plates that resemble an arm, but the infrabasals are missing, and the basals are poorly preserved, so the cup characters for this species cannot be fully diagnosed. Osagean species of Goniocrinus include G. incipiens (Hall, 1861) from the Burlington Limestone, which has large infrabasals and radials, and small basals forming a constricted circlet; and $G$. harrisi (Miller, 1880) from the Edwardsville Formation, which has infrabasals so small they are nearly covered by the stem attachment area, and the basals and radials are nearly equal in size. Goniocrinus sceletus n. sp. is unique in having large radials and distinct apical pits at the cup plate corners.

Superfamily SCYTALOCRINACEA Moore and Laudon, 1943

Family SCYTALOCRINIDAE Moore and Laudon, 1943 Genus LogocrinUs Goldring, 1923

Type species._Logocrinus geniculatus Goldring, 1923, by original designation.

Diagnosis.-Crown tall, narrow; cup high cone; plates smooth; three anal plates in cup; radial facets plenary with a gape between first primibrachial, and a strong fulcral ridge; first primibrachial trapezoidal, wider at base; two to three primibrachials in each ray, ten arms total, slender, with ramules, rarely pinnules at the distal ends; brachials cuneate with zigzag syzygial pairs.

LOGOCRINUS WARRENI (Laudon et al., 1952) n. comb. Figures 2.6, 3.9-3.11

Cradeocrinus warreni LAUDON ET AL., 1952, p. 551, pl. 65, figs. 18-21, pl. 69, fig. 3.

Logocrinus warreni MCINTOSH, 1983, p. 369, nomen nudum. Logocrinus martini ROESER, 1986, p. 185, nomen nudum.

TABLE 7-Measurements, in mm, of holotype of Goniocrinus sceletus n. $\mathrm{sp}$

\begin{tabular}{|c|c|c|c|c|c|c|c|c|}
\hline \multirow{2}{*}{$\begin{array}{c}\text { Crown } \\
\mathrm{H}\end{array}$} & \multicolumn{2}{|c|}{ Cup } & \multicolumn{2}{|c|}{ Infrabasal (A) } & \multicolumn{2}{|c|}{ Basal (A-B) } & \multicolumn{2}{|c|}{ Radial (A) } \\
\hline & $\mathrm{H}$ & $\mathrm{W}$ & $\mathrm{H}$ & $\mathrm{W}$ & $\mathrm{H}$ & $\mathrm{W}$ & $\mathrm{H}$ & $\mathrm{W}$ \\
\hline 24.0 & 2.6 & $2.1-5.3$ & 1.0 & 1.3 & 1.0 & 1.3 & 1.4 & 2.0 \\
\hline
\end{tabular}


Diagnosis.-A species of Logocrinus with relatively high infrabasals and radials that are not flared as in the type species; ramules on every fourth secundibrachial.

Material examined.-Five specimens, CMCIP 46162, 46163, 46164 (Figs. 2.6, 3.10), 46165 (Fig. 3.9), 46166 (Fig. 3.11).

Occurrence.-The Banff Formation of Alberta and the Meadville Shale Member of the Cuyahoga Formation at Richfield, Ohio.

Discussion.-Logocrinus and Cradeocrinus (Goldring, 1923) are similar genera, but the latter differs in having peneplenary, crescentic radial facets and brachials that are rectangular. Cradeocrinus warreni Laudon et al. (1952) is herein assigned to Logocrinus warreni because of its straight, plenary radial facets and cuneate secundibrachials that appear to exhibit syzygial pairs typical of the genus (Laudon et al., 1952, pl. 69, fig. 3). The specimens from the Meadville Shale appear to be conspecific with $L$. warreni from the Banff Formation, although they are somewhat larger. Roeser (1986) proposed that the Meadville Shale specimens were a new species, but they do not appear to have uniquely different characters relative to those of $L$. warreni from the Banff Formation.

Cradeocrinus dendratus Laudon and Severson (1953) from the Lodgepole Limestone, Montana, is also assignable to Logocrinus (McIntosh, 1983, p. 369). It differs from L. warreni in having an extremely high cup, which is nearly cylindrical, and very small arms that have ramules proximally and pinnules distally.

Logocrinus has previously been reported only from the Givetian and Frasnian stages of the Devonian. Recognition of $L$. warreni extends the range of the genus into the Kinderhookian.

\section{Genus Histocrinus Kirk, 1940}

Type species.-Poteriocrinus coreyi Worthen, 1875; by original designation.

Diagnosis. - Cup low, bowl-shaped to subconical, infrabasals visible in side view; basals prominent, may be slightly swollen; radial facets peneplenary, slightly crescentic; A ray may or may not be atomous, other rays branch once on primibrachial two; total of nine or 10 robust arms; brachials cuneate; pinnules robust.

Discussion.-Histocrinus and Decadocrinus have similar arm morphology but may be distinguished by the hidden infrabasals and plenary radial facets of Decadocrinus (Kammer and Ausich, 1992, 1993).

\section{HistocRinUs AEgINA (Hall, 1863) new combination} Figures 2.8, 3.6-3.8

Scaphiocrinus (Poteriocrinus) aegina HALl, 1863, p. 57. HALL AND WhitFIELD, 1875, p. 174, pl. 12, figs. 11, 12.

Decadocrinus aegina (HALL, 1863). WACHSMUTH AND SPRINGER, 1880, p. 119. BASSLER AND MOODEY, 1943, p. 405.

Histocrinus aegina (HALL, 1863). ROESER, 1986, p. 195, nomen nudum.

Decadocrinus baumgardneri LAUDON AND BEANE, 1937, p. 258, pl. 18, fig. 10; BASSLER AND MOODEY, 1943, p. 405.

Diagnosis.-A species of Histocrinus with cup plate ornamentation ranging from strong ridges crossing plate sutures to swollen basals, and apical pits at plate corners; atomous A ray, nine arms total; cuneate brachials form a slight zig-zag pattern; column pentagonal proximally, round distally, heteromorphic.

Material examined.-Five specimens from Richfield, CMCIP 46167, 46168 (Figs. 2.8, 3.8), 46169 (Fig. 3.7), 46171, 46172; three specimens from Lodi, CMNH 5748-14(2), 5955
(Fig. 3.6); and the holotype of Decadocrinus baumgardneri Laudon and Beane, 1937, SUI 2163.

Occurrence.-The Meadville Shale Member of the Cuyahoga Formation at Richfield and Lodi, Ohio, and the Maynes Creek Formation, Iowa.

Discussion.-Decadocrinus baumgardneri Laudon and Beane, 1937, from the Maynes Creek Formation of Iowa is judged to be conspecific with $H$. aegina, on the basis of its nodose basals and robust arms, with cuneate brachials, that branch on primibrachial two; it is placed in synonymy.

Other species of Histocrinus include $H$. coreyi, $H$. juvenis (Meek and Worthen, 1869), and H. graphicus (Miller and Gurley, 1890), all from the Osagean with smooth cup plates. Only one, the type species $H$. coreyi, has an atomous A ray. Kammer and Ausich (1992, p. 471) questionably assigned Decadocrinus stellatus Lane and Howell (1986) from the late Osagean to Histocrinus? stellatus because it had strongly ornamented, stellate cup plates with strong ridges and deep pits, rather than smooth plates. Other characters, particularly the visible infrabasals, peneplenary radial facets, and atomous A ray, are a better fit to Histocrinus. Histocrinus aegina, with its strongly ornamented cup plates, is very similar to H.? stellatus, suggesting a close phylogenetic relationship, and that the query should be removed to make simply Histocrinus stellatus.

Family CERCIDOCRINIDAE Moore and Laudon, 1943 Genus CUYAHOGACRINUS new genus

Diagnosis.-Crown tall, expanded; aboral cup medium height, conical; infrabasals clearly visible in side view; basals largest plates in cup; radials wider than high, peneplenary facets, straight, small notch between adjacent radials; anal plates unknown; primibrachial one axillary on B and E rays, primibrachial three axillary on A ray; higher axillaries swollen; arms slender with cuneate brachials; arm branching endotomous with up to five bifurcations in line per ray; column subpentagonal, heteromorphic.

Etymology.- Named for the Cuyahoga Formation in northern Ohio.

Discussion.-Cuyahogacrinus is most similar to Cercidocri$n u s$, having a cup that is essentially identical. Cercidocrinus also has endotomous arm branching, with up to four bifurcations in line per ray, and in Cercidocrinus bursaeformis (White, 1862) the A ray has three primibrachials as in Cuyahogacrinus. However, these genera may be readily separated in that Cuyahogacrinus has slender arms that are widely separated with cuneate brachials, unlike the closely abutting arms of Cercidocrinus with very short and wide brachials that may be slightly cuneate.

Cuyahogacrinus shares many arm characters with Abrotocrinus. In both genera the arms branch on primibrachial one in the B-E rays, and on higher primibrachials in the A ray, which may also be atomous in Abrotocrinus (Kammer and Ausich, 1993, table 2). The arms are narrow with cuneate brachials, swollen axillaries, and well developed pinnules; and if there are more than three bifurcations in line per ray, the branching pattern is endotomous, as in the holotype of $C$. lodiensis and specimens of $A$. unicus (Hall, 1861) and A. coreyi (Meek and Worthen, 1869).

However, the cups differ in that Cuyahogacrinus has a conical cup with clearly visible infrabasals in side view, whereas Abrotocrinus has a bowl-shaped cup with the infrabasals not visible in side view because they are invaginated and typically covered by the stem attachment area. This raises the possibility that Abrotocrinus evolved from Cuyahogacrinus as the cup changed from a cone to bowl shape by invagination of the infrabasals. 

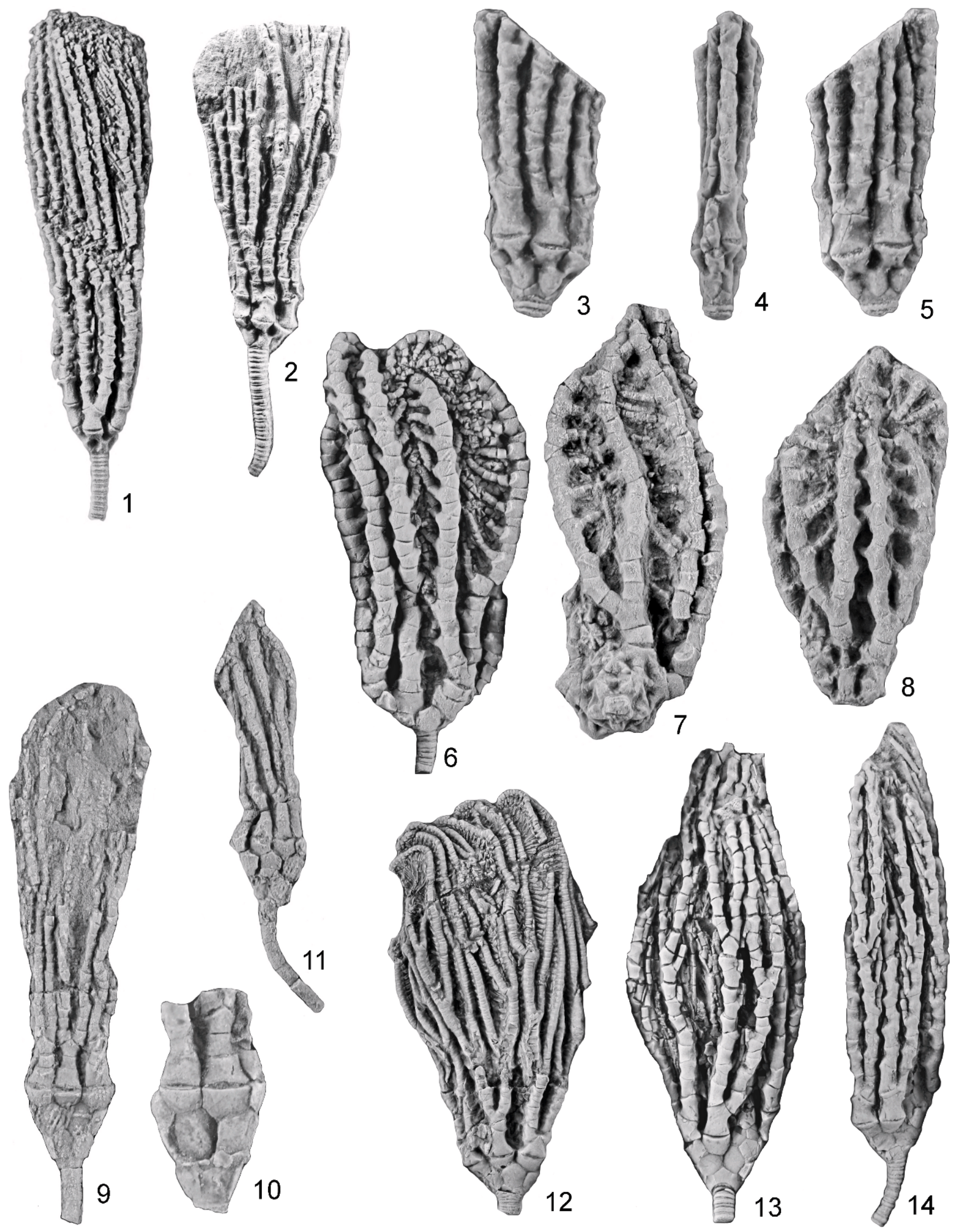
TABLE 8-Measurements, in mm, of holotype for Cuyahogacrinus lodiensis n.gen. n. sp.

\begin{tabular}{|c|c|c|c|c|c|c|c|c|}
\hline \multirow{2}{*}{$\begin{array}{c}\text { Crown } \\
\mathrm{H}\end{array}$} & \multicolumn{2}{|c|}{ Cup } & \multicolumn{2}{|c|}{ Infrabasal (A) } & \multicolumn{2}{|c|}{ Basal (E-A) } & \multicolumn{2}{|c|}{ Radial (A) } \\
\hline & $\mathrm{H}$ & $\mathrm{W}$ & $\mathrm{H}$ & $\mathrm{W}$ & $\mathrm{H}$ & $\mathrm{W}$ & $\mathrm{H}$ & $\mathrm{W}$ \\
\hline 73.0 & 7.6 & $5.3-15.5$ & 2.3 & 3.8 & 4.8 & 4.5 & 2.5 & 5.5 \\
\hline
\end{tabular}

\section{CUYAHOGACRINUS LODIENSIS new species}

Figures 2.5, 3.12

Diagnosis.-Same as for genus.

Description.-Crown tall, large, expanded (Table 8). Aboral cup medium height, conical, width to height ratio 2.0; cup plates smooth, no apical pits at corners; infrabasals visible in side view, forming a vertical wall with the proxistele, wider than high; basals largest plates in the cup, hexagonal, equidimensional; radials wider than high, with straight to slightly arcuate peneplenary facets that are nearly plenary, small gape between radials and primibrachials; small notches between radials. Anal plates unknown, but a few plates of the anal tube visible between the arms. Primibrachial one axillary on $\mathrm{E}$ and $\mathrm{B}$ rays, but primibrachial three axillary on $\mathrm{A}$ ray, $\mathrm{C}$ and $\mathrm{D}$ rays covered; swollen axillaries above first axillary; maximum of five bifurcations in line per ray with endotomous arm branching; arms narrow; brachials cunneate; pinnules long, slender. Column subpentagonal, heteromorphic.

Etymology.-Named for the locality where the holotype was found.

Material examined.-The holotype CMNH 005598(Figs. 2.5, 3.12), a complete crown, and the paratype CMNH 005676, a set of arms. Both collected by Gary Meszaros.

Occurrence.-The Meadville Shale Member of the Cuyahoga Formation at Lodi, Ohio.

Discussion.-The A radial has two holes from air abrasive damage during preparation, and several brachials also exhibit abrasive damage from cleaning with an air abrasive machine.

\section{Genus AsCETOCRINUS Kirk, 1940}

Type species.-Scaphiocrinus rusticellus White, 1863; by original designation.

Diagnosis.-Crown tall, slender; cup subconical to highbowl shape; apical pits at plate corners; infrabasals small, vertical, visible in side view; basals and radials similar in size; radial facets plenary, slightly arcuate, with prominent gape between first primibrachial; three anal plates in cup, although anal-X and right tube plate are narrow and parallel and sit directly on radianal and are mostly above the radials they touch; primibrachial one axillary on all rays; arms branch isotomously up to three times in each ray; brachials strongly cuneate, with zig-zag appearance; pinnules prominent; column circular to subpentagonal, heteromorphic.

Discussion.-Kirk (1940, p. 324) stated that Ascetocrinus has endotomous arm branching, which is repeated by Moore et al. (1978, p. T652). However, the only previous published illustration of this genus is a non-type A. rusticellus in Springer (1926, pl. 16, fig. 11), which seems to have isotomous branching, as do the specimens of $A$. whitei (Hall, 1861) below.
Ascetocrinus is similar to Cosmetocrinus, but differs in having the narrow and parallel anal $\mathrm{X}$ and right tube plates that sit directly above the radianal, and the apical pits at plate corners.

AsCETOCRINUS WHITEI (Hall, 1861)

Figures 2.9-2.11, 3.1-3.5

Scaphiocrinus whitei HALL, 1861, p. 7.

Poteriocrinus whitei (HALL, 1861). WACHSMUTH AND SPRINGER, 1880, p. 112.

Ascetocrinus whitei (HALl, 1861). KIRK, 1940, p. 325; BASSLER AND MoODEY, 1943, p. 312.

Scaphiocrinus subcarinatus HALL, 1863, p. 58. HALL AND WhitfiELD, 1875, p. 176, pl. 12, figs. 13, 14.

Pachylocrinus subcarinatus (HALL, 1863). BASSLER AND Moodey, 1943, p. 584.

Ascetocrinus subcarinatus (HALL, 1863). RoESER, 1986, p. 206, xnomen nudum.

Diagnosis.-A species of Ascetocrinus with deep apical pits at the cup plate corners, producing strong ridges crossing from the basals to the radials.

Material examined.-From Richfield, Ohio, CMCIP 46173 (Figs. 2.9-2.11, 3.3-3.5) and CMCIP 46174; from Burlington, Iowa, the holotype of $A$. whitei, USNM S2579 (Fig. 3.1).

Occurrence.-The Meadville Shale Member of the Cuyahoga Formation at Richfield, Ohio; and the lower part of the early Osagean Burlington Limestone, Burlington, Iowa.

Discussion.-The holotype of $A$. whitei from the lower Burlington Limestone is illustrated for the first time herein, where it can be seen that it is conspecific with the specimens of A. subcarinatus from the Meadville Shale, which are placed in synonymy. There are two recognized species of Ascetocrinus, the younger type species $A$. rusticellus from the upper part of the Burlington Limestone (Springer, 1926, pl. 16, fig. 11), and the older $A$. whitei from the lower part of the Burlington Limestone and the Meadville Shale. They are distinguished from one another by the much deeper apical pits on the cup of $A$. whitei.

\section{Family APHELECRINIDAE Strimple, 1967 Genus APHELECRINUS Kirk, 1944}

Type species.-Aphelecrinus elegans Kirk, 1944; by original designation.

Diagnosis. - Crown moderately high, slender to slightly expanded; cone-shaped aboral cup, plates smooth; infrabasals clearly visible in side view, half as high as basals; basals and radials similar in size; radials with plenary facets, straight; three anal plates in cup; primibrachial one axillary in all rays, usually higher than wide; arms branch a second time about halfway along length producing isotomous branching with 20 arms total; brachials cuneate; column subpentagonal to circular, heteromorphic.

Discussion.-Aphelecrinus is similar to Cosmetocrinus. See discussion below for Cosmetocrinus.

\section{APHELECRINUS GRACILIS new species}

Figure 3.13, 3.14

Diagnosis.-A species of Aphelecrinus with elongate, cuneate brachials that form a zig-zap pattern along the arms.

FIGURE 3-1-5, Ascetocrinus whitei (Hall, 1861): 1, anterior view, holotype, USNM S2579, Burlington Limestone, Iowa, $\times 1.5 ; 2$, anterior view, syntype of Scaphiocrinus subcarinatus Hall, 1863, NYSM 6139, $\times 2.0 ; 3-5$, B ray, posterior, and D-E ray views, CMCIP 46173, $\times 3.0 ; 6-8$, Histocrinus aegina (Hall, 1863): 6, anterior view, CMNH 5955, ×1.5; 7, C ray view, CMCIP 46169, ×2.0; 8, C ray view, CMCIP 46168, ×2.0; 9-11, Logocrinus warreni (Laudon et al., 1952): 9, anterior view, CMCIP 46165, $\times 2.0 ; 10$, B-C rays view, CMCIP 46164, ×3.0; 11, anterior view, CMCIP 46166, $\times 2.0 ; 12$, Cuyahogacrinus lodiensis n. gen. n. sp., A ray view, holotype, CMNH 5598, $\times 1.0 ; 13$, 14, Aphelecrinus gracilis n. sp.: 13, posterior view, holotype, CMNH 5718-26, $\times 1.5 ; 14$, D ray view, paratype, CMNH 5678-45, $\times 1.5$. 
TABLE 9-Measurements, in mm, of holotype for Aphelecrinus gracilis n. $\mathrm{sp}$.

\begin{tabular}{|c|c|c|c|c|c|c|c|c|}
\hline \multirow{2}{*}{$\begin{array}{c}\text { Crown } \\
\mathrm{H}\end{array}$} & \multicolumn{2}{|c|}{ Cup } & \multicolumn{2}{|c|}{ Infrabasal (D) } & \multicolumn{2}{|c|}{ Basal (D-E) } & \multicolumn{2}{|c|}{ Radial (D) } \\
\hline & $\mathrm{H}$ & $\mathrm{W}$ & $\mathrm{H}$ & $\mathrm{W}$ & $\mathrm{H}$ & $\mathrm{W}$ & $\mathrm{H}$ & $\mathrm{W}$ \\
\hline 57.0 & 7.3 & $3.3-9.7$ & 2.2 & 2.7 & 2.7 & 3.3 & 2.3 & 3.7 \\
\hline
\end{tabular}

Description.-Crown slender, subcylindrical (Table 9). Aboral cup cone shaped, medium height; plates smooth, lacking ornamentation; infrabasals small, upright, visible in side view; basals hexagonal, approximately equidimensional; radials wider than high, plenary facets slightly crescentic. Three anal plates in cup; radianal largest; anals arranged in typical advanced cladid arrangement with anal $X$ to the left and above of the radianal, and the right tube plate above the radianal. The base of the anal sac exposed between $\mathrm{C}$ and $\mathrm{D}$ rays; composed of smooth, hexagonal plates, with distinct pores along the sutures. First primibrachial axillary, higher than wide. Arm branching isotomous, with two bifurcations per ray for a total of 20 arms. Brachials short, cuneate, forming a zig-zag pattern; pinnules present, one per brachial, robust and elongate. Column circular, heteromorphic with distinct nodals and internodals.

Etymology._-Gracilis, Latin for slender.

Material examined.-The holotype, CMNH 5718-26 (Fig. 3.13), and paratype, CMNH 5678-45 (Fig. 3.14).

Occurrence.-The Meadville Shale Member of the Cuyahoga Formation at Lodi, Ohio.

Discussion.-Aphelecrinus gracilis resembles Acylocrinus lyriope, also from the Meadville Shale, but the former has a conical rather than bowl-shaped cup, three anal plates rather than one, and two bifurcations per ray rather than one, for a total of 20 arms rather than 10, with the second bifurcation about half way up the arms as in other species of Aphelecrinus, but not one third of the distance as in Paracosmetocrinus richfieldensis. It is larger and longer than other Early Mississippian Aphelecrinus, including the Kinderhookian (Maynes Creek Formation) A. elegantulus (Wachsmuth and Springer in Miller, 1889) and the Osagean (Burlington Limestone) $A$. delicatus (Meek and Worthen, 1860) and $A$. meeki (Kirk, 1941). These other species of Aphelecrinus have the same overall morphology of the cup and arms, but all are much smaller and the cuneate brachials are shorter and do not form a zig-zag pattern.

\section{Genus Cosmetocrinus Kirk, 1941}

Type species.-Cosmetocrinus gracilis Kirk, 1941; by original designation.

Diagnosis.-Crown tall, slender; conical to high bowlshaped aboral cup, medium height, smooth plates; infrabasals clearly visible in side view, half as high as basals; basals and radials similar in size; radials with plenary facets, straight; three anal plates in cup; primibrachial one axillary in all rays, with two or three higher bifurcations per ray and uneven isotomous branching; brachials subcuneate to cuneate; column subpentagonal to circular, thin plates, homeomorphic.

Discussion.-Many species previously assigned to Cosmetocrinus have been reassigned to either Paracosmetocrinus Strimple, 1967 or Aphelecrinus Kirk, 1944 (Webster, 2003). Paracosmetocrinus differs in that the first branching on the A ray is higher than the first primibrachial, and Aphelecrinus has only two isotomous bifurcations per ray but is very similar to Cosmetocrinus otherwise. Cosmetocrinus occurs only in the Lower Mississippian with certainty, notwithstanding Lane et al. (1997) defining C. parvus on the basis of poorly preserved specimens from the Famennian of China.

\section{COSMETOCRINUS CRINEUS (Hall, 1863)}

Figure 4.1, 4.2

Poteriocrinus crineus HALL, 1863, p. 56. HALL AND WHITFIELD, 1875, p. 172, pl. 12, figs. 6, 7.

Cosmetocrinus crineus (HALL, 1863). KIRK, 1941, p. 87; BASSLER AND MOODEY, 1943, p. 373; RoESER, 1986, p. 230, pl. 9, figs. 5, 6, nomen nudum.

Aphelecrinus crineus (HALL, 1863). STRIMPLE, 1967, p. 81.

Diagnosis.-A species of Cosmetocrinus with a high, bowlshaped aboral cup.

Material examined.-The holotype, NYSM 6137 (Fig. 4.2), and CMCIP 46182 (Fig. 4.1)

Occurrence.-The Meadville Shale Member of the Cuyahoga Formation at Richfield, Ohio.

Discussion.-Cosmetocrinus crineus is nearly indistinguishable from C. gracilis from the late Osagean Edwardsville Formation at Indian Creek, Indiana (Kirk, 1941; Kammer and Ausich, 1992). The aboral cup of $C$. crineus is slightly more bowl-shaped than the more conical cup of $C$. gracilis, which could just be preservational in origin, but otherwise there seem to be few obvious differences. If more, and better preserved, specimens were to be found in the Meadville Shale, or specimens of Cosmetocrinus referable to either of these two species were found in rocks of the intervening early Osagean, future workers could choose to place $C$. gracilis in synonymy with $C$. crineus. However, at this time it seems unwise to do so for two reasons. First, it is not absolutely clear that these two species are identical, based on the preservational limitations of two imperfect specimens (Fig. 4.1, 4.2). And, second, the wide temporal gap of $10 \mathrm{~m} . \mathrm{y}$. between the late Kinderhookian and late Osagean (Gradstein et al., 2004) increases the chance for homoplasy.

\section{Genus PARACOSMETOCRINUs Strimple, 1967}

Type species.-Paracosmetocrinus strakai Strimple, 1967; by original designation.

Diagnosis. - Crown tall, slender; bowl-shaped to conical aboral cup, medium height, smooth plates; infrabasals clearly visible in side view, half as high as basals; basals and radials similar in size; radials with plenary facets, straight; three anal plates in cup; primibrachial one axillary in all rays, except A ray with three or more primibrachials before first branching; two or three higher bifurcations per ray, except A ray with one less bifurcation, with uneven isotomous branching; brachials subcuneate to cuneate; column subpentagonal to circular, heteromorphic.

Discussion.-Paracosmetocrinus is known only from the Kinderhookian and includes ten named species (Webster, 2003).

PARACOSMETOCRINUS RICHFIELDENSIS

(Worthen, 1882) new combination Figures 2.7, 4.3-4.6

Poteriocrinus richfieldensis WORTHEN, 1882, p. 15. WORTHEN, 1883 , p. 285, pl. 30, fig. 5.

Cosmetocrinus richfieldensis (WORTHEN, 1882). KIRK, 1941, p. 88; BASSLER AND MOODEY, 1943, p. 374; VAN SANT AND LANE, 1964, p. 94.

Aphelecrinus richfieldensis (WORTHEN, 1882). LAUDON AND SEVErson, 1953, p. 521. STRIMPle, 1967, p. 81.

Paracosmetocrinus richfieldensis (WORTHEN, 1882). ROESER, 1986, p. 215, nomen nudum.

Diagnosis.-A species of Paracosmetocrinus with a bowlshaped cup, infrabasals horizontal; long first primibrachials 

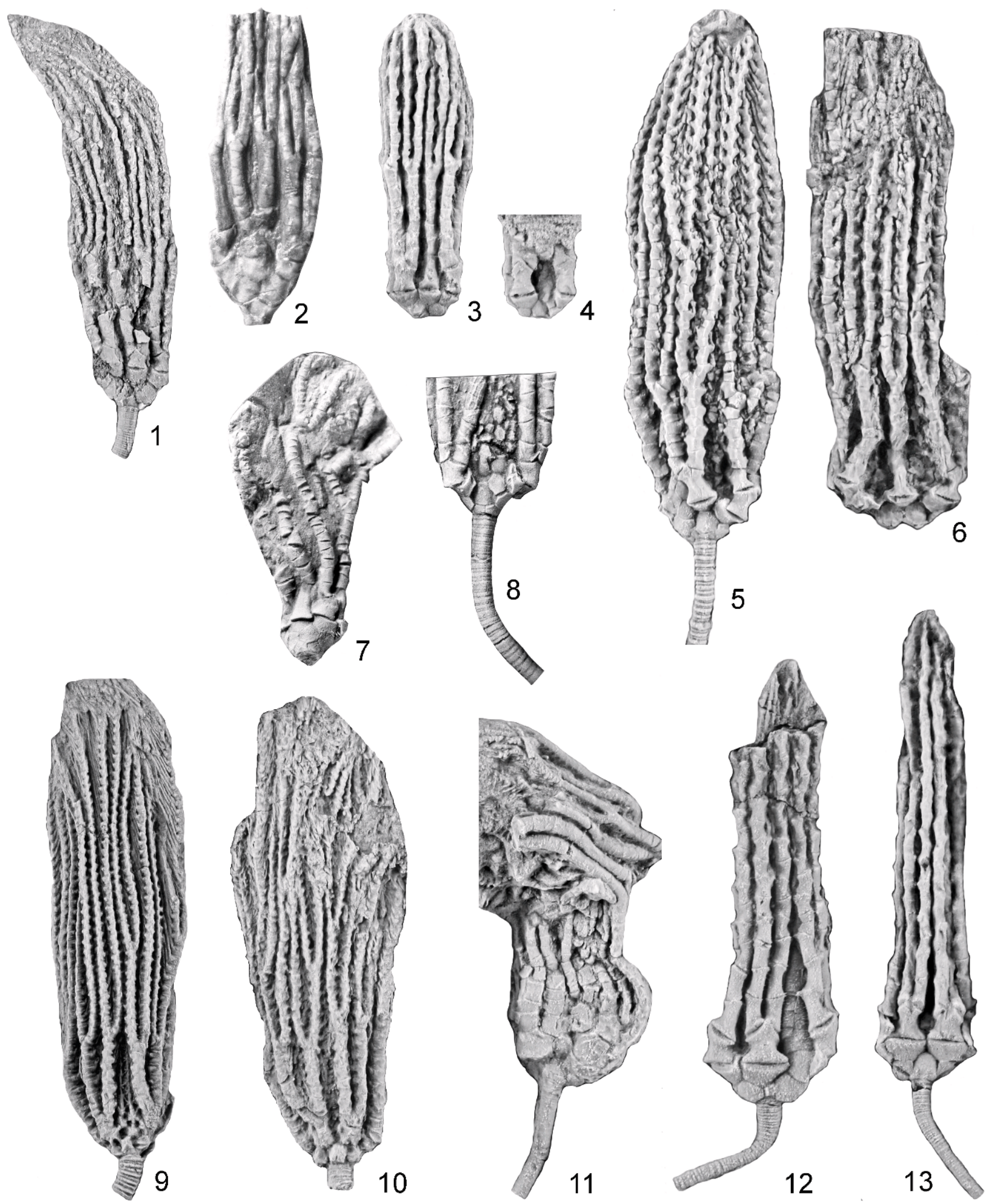

Figure 4-1, 2, Cosmetocrinus crineus (Hall, 1863): 1, anterior view, CMCIP 46182, $\times 1.0 ; 2$, E ray view, holotype, NYSM 6137, $\times 1.0 ; 3-6$, Paracosmetocrinus richfieldensis (Worthen, 1882): 3, anterior view; 4, posterior view, CMCIP 46179, $\times 2.0 ; 5$, B-C ray view, CMNH 5681, $\times 1.5 ; 6$, anterior view, CMNH 5748-25, $\times 1.5 ; 7,8$, Paracosmetocrinus corycia (Hall, 1863): 7, anterior view, holotype, NYSM 6138, $\times 2.0 ; 8$, posterior view, holotype of Poteriocrinus pleias Hall, 1863, NYSM 6124, ×2.0; 9, 10, Pachylocrinus subtortuosus (Hall, 1863): 9, posterior view, CMCIP 46183, $\times 1.0 ; 10$, anterior view, CMCIP 46184, ×1.0; 11, Lebetocrinus ohioensis n. sp., posterior view, holotype, CMCIP 46106B, ×2.0; 12, 13, Acylocrinus lyriope (Hall, 1863 ); 12 , posterior view, CMCIP $46187, \times 2.0 ; 13$, anterior view, CMNH $5881, \times 1.5$. 
constricted at midlength, seven to 11 primibrachials on the A ray; brachials cuneate, forming zig-zag pattern.

Material examined.-CMCIP 46152, 46175, 46176, 46177 (Fig. 2.7), 46178, 46179 (Fig. 4.3, 4.4) from Richfield, Ohio; and CMNH 5681 (Fig. 4.5) and CMNH 5748(\#25) (Fig. 4.6) from Lodi, Ohio.

Occurrence.-The Meadville Shale Member of the Cuyahoga Formation at Richfield and Lodi, Ohio.

Discussion.- Specimens from Richfield are all small crowns, generally 2 to $3 \mathrm{~cm}$ in height, with a maximum of two bifurcations per ray. The two specimens from Lodi have larger crowns, each about $6 \mathrm{~cm}$ in height, with one (CMNH 5681) displaying a single third bifurcation on the $\mathrm{C}$ ray. Other species include $P$. madisonensis (Laudon and Severson, 1953) from the Lodgepole Limestone with seven primibrachials on the A ray, $P$. strakai from the Wassonville Formation with four primibrachials on the A ray, and $P$. cirrifer (Laudon, 1933) from the Gilmore City Formation with three primibrachials on the A ray, all of which lack the constricted first primibrachials as in $P$. richfieldensis.

\section{PARACOSMETOCRINUS CORYCIA \\ (Hall, 1863) new combination}

Figure 4.7, 4.8

Poteriocrinus corycia HALL, 1863, p. 57. HALL AND WHITFIELD, 1875, p. 173, pl. 12, fig. 9.

Pachylocrinus corycia (HALl, 1863). BASSLER AND MoOdeY, 1943, p. 580

Poteriocrinus pleias Hall, 1863, p. 57. HALl AND WhitFiEld, 1875 , p. 175 , pl. 12 , fig. 8.

Decadocrinus pleias (HALL, 1863). WACHSMUTH AND SPRINGER, 1880, p. 119.

Hypselocrinus pleias (HALL, 1863). KIRK, 1940, p. 327. BASSLER AND MOODEY, 1943, p. 520.

Paracosmetocrinus corycia (HALL, 1863). ROESER, 1986, p. 223, nomen nudum.

Diagnosis. - A species of Paracosmetocrinus with a conical cup, infrabasals upright; first primibrachials not constricted at midlength, and five primibrachials on the A ray; brachials cuneate to rectangular, not forming zig-zag pattern.

Material examined.-NYSM 6138 (Fig. 4.7), the holotype of Poteriocrinus corycia, and NYSM 6124 (Fig. 4.8), the holotype of Poteriocrinus pleias, from Richfield, Ohio; and CMNH 4867 and 4868 from Weymouth, between Lodi and Richfield, Ohio.

Occurrence.-The Meadville Shale Member of the Cuyahoga Formation at Richfield and Weymouth, Ohio.

Discussion.-The holotype of Poteriocrinus corycia exposes the A ray with five primibrachials below the first branching and an $\mathrm{E}$ ray with three bifurcations in line, characters consistent with Paracosmetocrinus. The holotype of Poteriocrinus pleias exposes the posterior interray with three anal plates and the proximal arms of the $\mathrm{C}$ and $\mathrm{D}$ rays branching on the first primibrachial. These characters are consistent with either Paracosmetocrinus or Hypselocrinus, which may be why Kirk (1940) assigned it to Hypselocrinus, which is similar to Paracosmetocrinus, but only has 10 arms. Although this specimen could conceivably be assigned to Hypselocrinus, it seems more likely that it represents the posterior of the better preserved $P$. corycia and is, thus, placed in synonymy.

Paracosmetocrinus corycia is known from only a few incomplete specimens but it does have characters distinct from $P$. richfieldensis. It appears to be most similar to $P$. madisonensis (Laudon and Severson, 1953) from the Lodgepole Formation, which differs only slightly in having seven primibrachials on the A ray.
Superfamily LOPHOCRINACEA Bather, 1899 Family PACHYLOCRINIDAE Kirk, 1942

Genus PACHYLOCRINUS Wachsmuth and Springer, 1880

Type species.-Scaphiocrinus aequalis Hall, 1861; by original designation (Wachsmuth and Springer, 1880).

Diagnosis.-Crown tall, cylindrical to ovoid; aboral cup low, bowl-shaped; plates thick, margins fluted; infrabasals not visible in side view; basals typically bulbous, larger than radials; radials with plenary facets, slightly crescentic; three anals in cup; primibrachial two axillary in all rays; arm branching uneven isotomous, tending toward endotomous in some rays; three or four bifurcations in line per ray; brachials rectangular to cuneate; column circular, heteromorphic.

Discussion.-The genus Pachylocrinus was used as a "catch all" genus by Bassler and Moodey (1943) for assignment of 65 species of advanced cladids with two or more bifurcations per ray, particularly those species previously assigned to Poteriocrinites (or Poteriocrinus) or the invalid genus Scaphiocrinus (see Springer, 1911). Kammer and Ausich (1993, p. 619) reviewed 22 of these species from just the late Osagean-early Meramecian interval, recognizing just two valid species, the type species $P$. aequalis and $P$. asper (Worthen, 1882), and they reviewed the correct generic assignments for the remaining 20 species. Many other species were reassigned by various workers subsequent to Bassler and Moodey (1943), but 21 species, besides $P$. aequalis, P. asper, and P. subtortuosus, were listed by Webster (2003) as still assigned to Pachylocrinus. Many of these have been, or possibly will be, reassigned to other genera with further study, such as the six species from Ireland reassigned by Ausich and Sevastopulo (2001), or P. subcarinatus (Hall, 1863) reassigned to Ascetocrinus in the present study.

\section{PACHYLOCRINUS SUBTORTUOSUS (Hall, 1863)}

Figures 4.9, 4.10, 5.2

Scaphiocrinus subtortuosus HALL, 1863, p. 58. HALL AND WhitFIELD, 1875, p. 177, pl. 12, figs. 15, 16.

Decadocrinus subtortuosus (HALL, 1863). WACHSMUTH AND SPRINGER, 1880, p. 120; BASSLER AND MOODEY, 1943, p. 408

Pachylocrinus subtortuosus (HALL, 1863). ROESER, p. 239, nomen nudum; AUsICH, 1996, p. 249, fig. 17-7, no. 1.

Diagnosis.-A species of Pachylocrinus with strong, radiating ridges that create deep, apical pits at plate corners of the aboral cup; brachials strongly cuneate, forming slight zig-zag pattern from pinnular articulations.

Material examined.-Four specimens from Richfield, CMCIP 46183 (Figs. 4.9, 5.2), 46184 (Fig. 4.10), 46185, 46186. The holotype, NYSM 6125, was illustrated by both Hall and Whitfield (1875, pl. 12, figs. 15, 16) and Roeser (1986, pl. 11, fig. 5), but is not illustrated again because of its poor preservation. The preserved characters of the partially disarticulated cup and partial arms are clearly conspecific with the specimens illustrated herein.

Occurrence.-The Meadville Shale Member of the Cuyahoga Formation at Richfield, Ohio.

Discussion.-Pachylocrinus subtortuosus is only the third species of Pachylocrinus known with certainty from the Lower Mississippian. It is very similar to the type species, $P$. aequalis (see Kammer and Ausich, 1993, p. 619) from the late Osagean, which has fluted plate margins but lacks the very strong radiating ridges on the cup plates and the strongly developed pinnular articulations that give the arms a slight zig-zag appearance, as in P. subtortuosus. It differs from the other late Osagean species, $P$. asper, which has deep sutures between the cup plates and arm branching in a broad U-shaped pattern, 

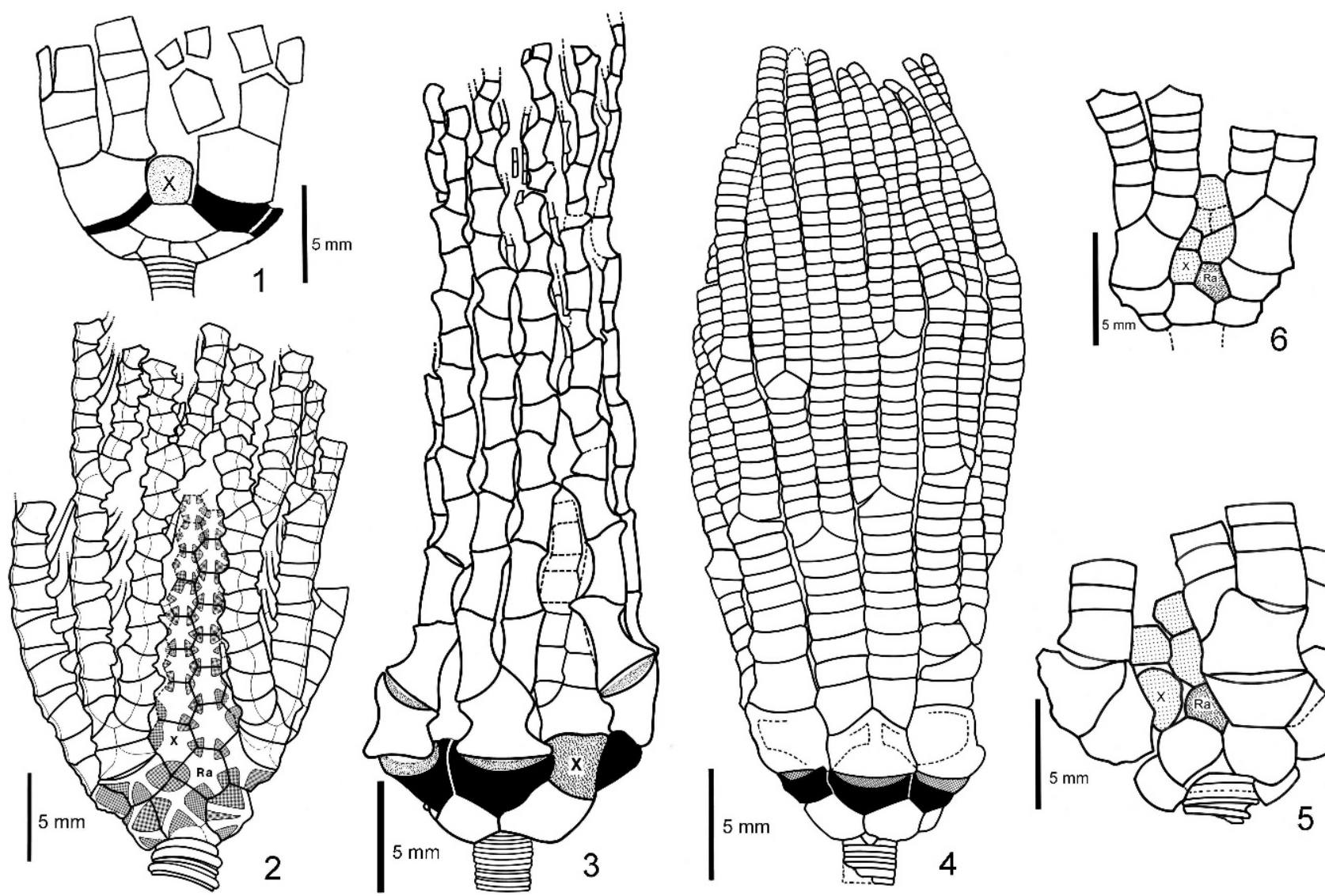

FIGURE 5-Plate diagrams; radials in black; $\mathrm{Ra}=$ radianal plate; $\mathrm{X}=$ anal $\mathrm{X}$ plate. 1, Lebetocrinus ohioensis $\mathrm{n}$. sp., holotype, posterior view, CMCIP 46106B; radials appear shortened because of aboral-adoral compression; 2, Pachylocrinus subtortuosus (Hall, 1863), posterior view, CMCIP 46183; 3, Acylocrinus lyriope (Hall, 1863), posterior view, CMCIP 46187; 4, 5, Linocrinus merope (Hall, 1863): 4, anterior view, CMCIP 46190; 5 , posterior view, CMCIP 46191; 6, Linocrinus paternus (Hall, 1863), posterior view, CMCIP 46194.

rather than the $\mathrm{Y}$-shaped pattern of both $P$. aequalis and $P$. subtortuosus.

Superfamily AgAssizocRINACEA S.A. Miller, 1889

Family BURSACRINIDAE Kirk, 1947

Genus LEBETOCRINUS Kirk, 1940

Type species.-Lebetocrinus grandis Kirk, 1940; by original designation.

Diagnosis.-Crown long; cup low bowl shape; infrabasals small, visible in side view; basals and radials larger, similar in size; radial facets plenary, slightly crescentic; one anal plate in cup; both cup and arm plates smooth, thin; first primibrachial axillary, uneven isotomous arm branching; proximal brachials wide, short; column homeomorphic, circular, columnals thin.

Discussion.-Lebetocrinus has previously been known only from the type species found in the late Osagean at several Indiana localities (Kammer and Ausich, 1992, p. 478).

\section{LEBETOCRINUS OHIOENSIS new species \\ Figures 4.11, 5.1}

Diagnosis.-A species of Lebetocrinus that has large, pentagonal first primibrachials, rather than lozenge-shaped first primibrachials; brachials rectangular.

Description.-Crown tall, cylindrical, although arms folded over by burial (Table 10). Cup low bowl; plates thin, smooth; infrabasals small, vertical, visible in side view; basals larger than infrabasals, but poorly preserved; radials largest plates in cup, wider than high, with slightly crescentic plenary facets. Only one anal plate in the cup, positioned between the $\mathrm{C}$ and
D radials, hexagonal(?), supporting flat plates of the anal sac that resemble brachials. Arms branching once on primibrachial one in the two visible rays, $\mathrm{C}$ and $\mathrm{D}$, and then again at least three times higher in an uneven isotomous pattern; proximal brachials flat, thin, wider than high rectangular; distal brachials rounded, not flat, slightly wider than high, rectangular, with pinnules. Column circular, homeomorphic with thin columnals.

Etymology.-For the state of Ohio.

Material examined.-The holotype, and only known specimen, CMCIP 46106B (Fig. 4.11).

Occurrence.-The Meadville Shale Member of the Cuyahoga Formation at Richfield, Ohio.

Discussion.-Lebetocrinus ohioensis has large, pentagonal first primibrachials that are unlike the lozenge-shaped first primibrachials of L. grandis, and the brachials are rectangular rather than rectangular to subcuneate. The radials appear short in lateral view (Fig. 5.1), but this is the result of aboraladoral compression so they are viewed nearly on end. This new species extends the range of the genus downward from the late Osagean to the late Kinderhookian.

TABLE 10-Measurements, in mm, of holotype of Lebetocrinus ohioensis n. sp.

\begin{tabular}{|c|c|c|c|c|c|c|c|c|}
\hline \multirow{2}{*}{$\begin{array}{c}\text { Crown } \\
\mathrm{H}\end{array}$} & \multicolumn{2}{|c|}{ Cup } & \multicolumn{2}{|c|}{$\begin{array}{c}\text { Infrabasal } \\
\text { (C) }\end{array}$} & \multicolumn{2}{|c|}{ Basal (C-D) } & \multicolumn{2}{|c|}{ Radial (C) } \\
\hline & $\mathrm{H}$ & W & $\mathrm{H}$ & W & $\mathrm{H}$ & $\mathrm{W}$ & $\mathrm{H}$ & W \\
\hline$>35$ & $\begin{array}{r}4.6 \\
\text { (c }\end{array}$ & $\begin{array}{l}3.2-10.0 \\
\text { ished) }\end{array}$ & 1.1 & 1.9 & 2.1 & 4.6 & $\begin{array}{r}>2.0 \\
\quad(\mathrm{cru}\end{array}$ & $\begin{array}{l}4.0 \\
\text { ed) }\end{array}$ \\
\hline
\end{tabular}



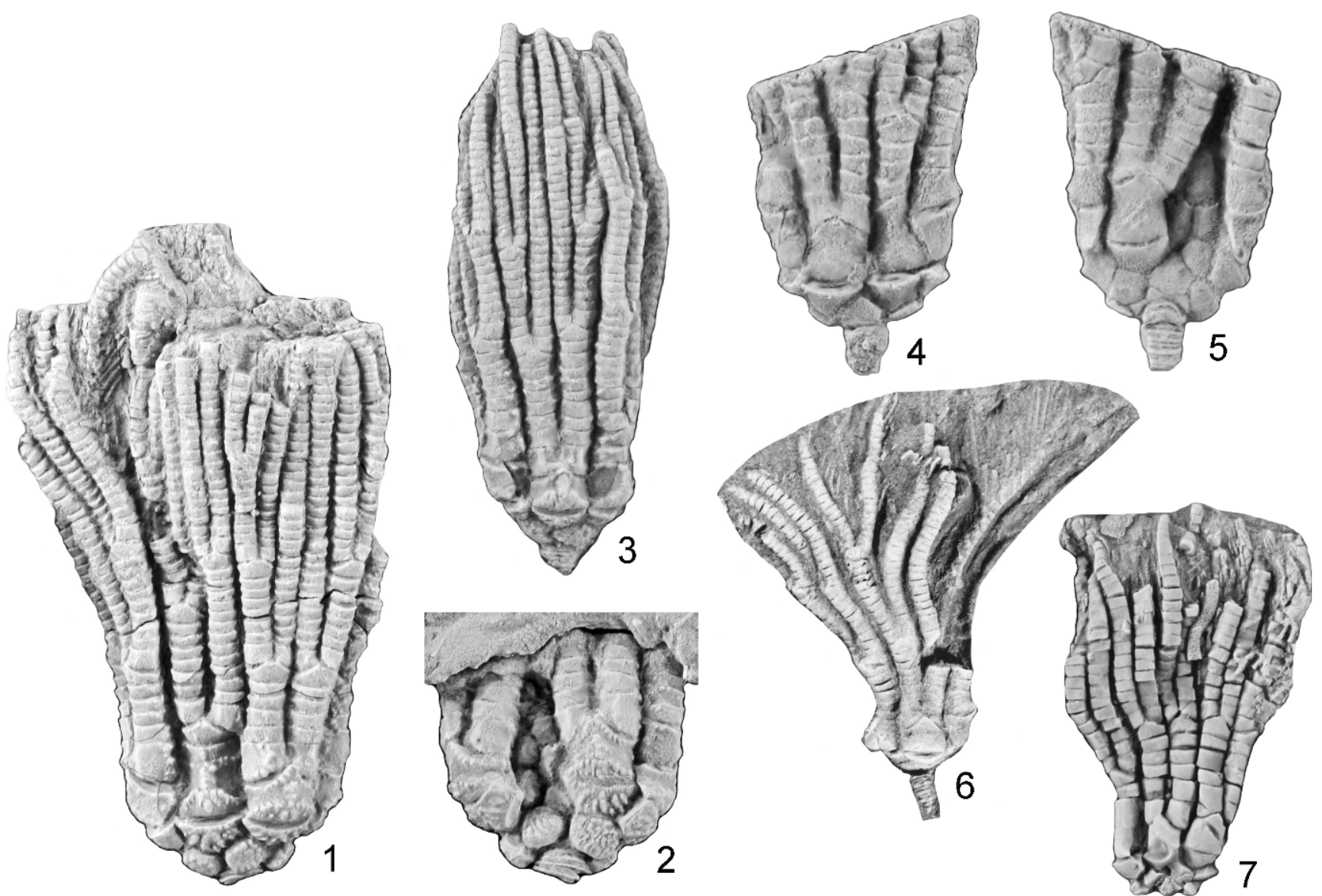

FIGURE 6-1-3, Linocrinus merope (Hall, 1863): 1, anterior view; 2, posterior view, CMCIP 46191, $\times 2.0 ; 3$, anterior view, CMCIP 46190, $\times 2.0$; 4-7, Linocrinus paternus (Hall, 1863): 4, anterior view; 5, posterior view, CMCIP 46194, ×3.0; 6, E-ray view, holotype, NYSM 6133, ×2.0; 7, E-ray view (pit from preparation), CMNH 5807, $\times 2.0$.

\section{Superfamily DECADOCRINACEA Bather, 1890 \\ Family DECADOCRINIDAE Bather, 1890 \\ Genus ACYLOCRINUS Kirk, 1947}

Type species.-Acylocrinus tumidus Kirk, 1947; by original designation.

Diagnosis.-Crown tall, slender; cup low bowl shape, plates smooth; infrabasals small, generally not visible in side view; radials largest plates in cup, facets plenary, straight or slightly crescentic; one anal plate in cup; first primibrachial axillary in all rays, ten arms total; brachials cuneate; column heteromorphic, circular.

\section{ACYLOCRINUS LYRIOPE (Hall, 1863) n. comb.}

Figures 4.12, 4.13, 5.3

Poteriocrinus (Scaphiocrinus) lyriope HALl, 1863, p. 58. HALL AND WhitFIELD, 1875c, p. 175, pl. 12, fig. 10.

Decadocrinus lyriope (HALL, 1863). WACHSMUTH AND SPRINGER, 1880 (1879), p. 119 (342); BASSLER AND Moodey, 1943, p. 407.

Acylocrinus lyriope (HALL, 1863). ROESER, 1986, p. 249, nomen nudum.

Diagnosis.-A species of Acylocrinus with long, cuneate brachials.

Material examined.-Three specimens, CMCIP 46187

(Figs. 4.12, 5.3), 46188, and CMNH 5881 (Fig. 4.13).

Occurrence.-The Meadville Shale Member of the Cuyahoga Formation at Richfield and Lodi, Ohio.

Discussion.-This species is similar to both A. tumidus and $A$. depressus Kirk, 1947 from the lower and upper parts of the
Burlington Limestone, respectively, but differs in having much longer brachials. Acylocrinus lyriope extends the range of the genus from the early Osagean down to the late Kinderhookian.

Superfamily ZeACRINITACEA Bassler and Moodey, 1943

Family ZEACRINITIDAE Bassler and Moodey, 1943

Genus LiNOCRINUs Kirk, 1938

Type species.-Linocrinus wachsmuthi Kirk, 1938; by original designation.

Diagnosis.-Crown subcylindrical, expanded distally; aboral cup low, bowl shaped; surface of plates often coarse, or with ridges; infrabasals concealed by stem attachment area; basals slightly smaller than radials; radial facets plenary, straight; distinct suture gape between radials and first primibrachials; three anal plates in cup; primibrachial one axillary on B-E rays, three to five primibrachials on A ray; B-E ray arm branching endotomous with as many as four to six bifurcations in line per ray; A ray arm branching isotomous with two branchings; brachial plates with a coarse or granular surface, a median keel or ridge may be present, particularly on the axillary primibrachials; brachials short, rectangular to cuneate; column circular.

\section{LINOCRINUS MEROPE (Hall, 1863) new combination} Figures 5.4, 5.5, 6.1-6.3

Zeacrinus merope HALL, 1863, p. 60. HALl AND WHITFIELD, 1875 , p. 172 , pl. 12 , fig. 15.

Zeacrinites merope (HALL, 1863). BASSLER AND MOODEY, 1943, p. 728.

Linocrinus merope (HALL, 1863). ROESER, p. 259, nomen nudum. 
Diagnosis.-A species of Linocrinus with a medium-high, bowl-shaped cup, three primibrachials on the A ray, nodes and ridges on cup plates, carinate axillary primibrachials, rectangular brachials, and up to four endotomous arm branchings per ray.

Material examined.-The holotype, NYSM 6132, and CMCIP 46190 (Figs. 5.4, 6.3), 46191 (Figs. 5.5, 6.1, 6.2), 46193, 46195.

Occurrence.-The Meadville Shale Member of the Cuyahoga Formation at Richfield, Ohio.

Discussion.-Among the various species of Mississippian Linocrinus (Webster, 2003), L. compactus (Laudon, 1933) from the latest Kinderhookian Gilmore City Formation is most similar, if not conspecific, having nodose plate ornamentation and three primibrachials on the A ray. However, it differs in having up to six endotomous arm branchings per ray. The holotype of L. compactus, illustrated by Moore and Laudon (1944, pl. 64, fig. 23), has narrow, regenerated, distal arms where up to three branchings occur, suggesting their origin associated with regrowth of the arms after possible sublethal cropping by a predator.

\section{LINOCRINUS PATERNUS (Hall, 1863) n. comb.} Figures 5.6, 6.4-6.7

Zeacrinus paternus HAll, 1863, p. 59. HALl AND WHITFIELD, 1875, p. 177, pl. 12, fig. 17.

Zeacrinites paternus (HALL, 1863). BASSLER AND MoOdeY, 1943, p. 728.

Diagnosis.-A species of Linocrinus with a low, bowlshaped cup, three to five primibrachials on the A ray, smooth cup and brachial plates, rectangular brachials, and up to three endotomous arm branchings per ray.

Material examined.-The holotype, NYSM 6133 (Fig. 6.6); CMCIP 46194 (Figs. 5.6, 6.4, 6.5); and CMNH 5807 (Fig. 6.7).

Occurrence.-The Meadville Shale Member of the Cuyahoga Formation at Richfield and Lodi, Ohio.

Discussion.- Smooth plates are unusual in Linocrinus, but L. penicillus (Meek and Worthen, 1869), from both the lower and upper parts of the Burlington Limestone, has mostly smooth plates, except for subtle carinae on the primibrachials of some specimens.

\section{ACKNOWLEDGMENTS}

D. Meyer supervised the Master's thesis of Roeser at the University of Cincinnati where the late K. and A. Caster provided significant encouragement. All but two of the line drawings were prepared by Roeser, with mostly new photos prepared by Kammer. For making specimens available for study, we thank D. Meyer, B. Hunda, Cincinnati Museum Center, and J. Hannibal, Cleveland Museum of Natural History. E. Bragonje, West Virginia University, assisted with figure preparation. W. Ausich, D. Meyer, and F. Gahn provided helpful and constructive reviews.

\section{REFERENCES}

Ausich, W. I. 1980. A model for niche differentiation in Lower Mississippian crinoid communities. Journal of Paleontology, 54:273-288. Ausich, W. I. 1996. Phylum Echinodermata, p. 242-261. In R. M. Feldmann and M. Hackathorn (eds.), Ohio Fossils. Geological Survey of Ohio Bulletin 70.

Ausich, W. I. AND T. W. Kammer. 2008. Generic concepts in the Amphoracrinidae Bather, 1899 (Class Crinoidea) and evaluation of generic assignments of North American species. Journal of Paleontology, 82:1139-1149.

Ausich, W. I. AND N. G. LANE. 1982. Crinoids from the Edwardsville Formation (Lower Mississippian) of Indiana. Journal of Paleontology, 56:1343-1361.

Ausich, W. I. AND E. W. Roeser. 2012. Camerate and disparid crinoids from the late Kinderhookian Meadville Shale, Cuyahoga Formation of Ohio. Journal of Paleontology, 86:488-507.
Ausich, W. I. And G. D. Sevastopulo. 2001. The Lower Carboniferous (Tournaisian) crinoids from Hook Head, County Wexford, Ireland. The Palaeontological Society Monograph, 216:1-136.

Ausich, W. I., C. E. BRetT, AND H. Hess. 1999. Taphonomy, p. 50-54. In H. Hess, W. I. Ausich, C. E. Brett, and M. J. Simms (eds.), Fossil Crinoids. Cambridge University Press, Cambridge.

Ausich, W. I., T. W. Kammer, and N. G. Lane. 1979. Fossil communities of the Borden (Mississippian) delta in Indiana and northern Kentucky. Journal of Paleontology, 53:1182-1196.

BASSLER, R. S. AND M. W. MoODEY. 1943. Bibliographic and faunal index of Paleozoic pelmatozoan echinoderms. Geological Society of America Special Paper, 45, $734 \mathrm{p}$.

BASSlER, R. S. 1938. Pelmatozoa Palaeozoica. In W. Quenstedt (ed.), Fossilium catalogus, I: Animalia. Part 83: W. Junk, s'Gravenhage, $194 \mathrm{p}$.

BAther, F. A. 1890. British fossil crinoids. Annals and Magazine of Natural History, series 6, 5:310-334.

BATHER, F. A. 1899. A phylogenetic classification of the Pelmatozoa. British Association for the Advancement of Science (1898), 916-923.

BREZINSKI, D. K. 2009. Biostratigraphic distribution of Appalachian Carboniferous trilobites, p. 78-84. In S. F. Greb and D. R. Chesnut, Jr. (eds.), Carboniferous of the Appalachian and Black Warrior basins. Kentucky Geological Survey Special Publication 10, Series XII.

CARTER, J. L. 1987. Lower Carboniferous brachiopods from the Banff Formation of western Alberta. Geological Survey of Canada, Bulletin $378,183 \mathrm{p}$.

Collinson, C., C. B. Rexroad, And T .L. Thompson. 1971. Conodont zonation of the North American Mississippian, p. 353-394. In W. C. Sweet and S. M. Bergstrom (eds.), Symposium on Conodont Biostratigraphy, Geological Society of America Memoir 127.

Coogan, A. H., R. A. Heimlich, R. J. Malcuit, K. B. Bork, and T. L. LEWIS. 1981. Early Mississippian deltaic sedimentation in central and northeastern Ohio, p. 113-152. In T. G. Roberts (ed.), GSA Cincinnati '81: Field Trip Guidebooks, Vol. 1. Stratigraphy, sedimentology: American Geological Institute.

GAHN, F. J. AND T. K. BAUMiller. 2004. A bootstrap analysis for comparative taphonomy applied to Early Mississippian (Kinderhookian) crinoids from the Wassonville cycle of Iowa. Palaios, 19:17-38.

Gahn, F. J. AND T. W. Kammer. 2002. The cladid crinoid Barycrinus from the Burlington Limestone (Early Osagean) and the phylogenetics of Mississippian botryocrinids. Journal of Paleontology, 76:123-133.

GoldRING, W. 1923. The Devonian crinoids of the state of New York. New York State Museum Memoir 16, 670 p.

GORDON, M., JR., 1986. Late Kinderhookian (Early Mississippian) ammonoids of the western United States. Journal of Paleontology, Memoir 19, supplement to vol. 60 , no. 3, 36 p.

Gradstein, F., J. OgG, And A. Smith. 2004. A Geologic Time Scale. Cambridge University Press, $589 \mathrm{p}$.

HALl, J. AND R. P. Whitfield. 1875. Crinoidea of the Waverly Group. Ohio Geological Survey Report, Vol. 2. Geology and Palaeontology, pt. 2, Palaeontology, p. 162-179.

HALl, J. 1861. Descriptions of new species of Crinoidea from the Carboniferous rocks of the Mississippi Valley. Journal of the Boston Society of Natural History, 3:261-328.

HALL. J. 1863. Preliminary notice, of some species of Crinoidea from the Waverly Sandstone series of Summit Co., Ohio, supposed to be of the age of the Chemung Group of New York. Preprint of Seventeenth Annual Report of the Regents of the University of the State of NewYork, on the Condition of the State Cabinet of Natural History, and the Historical and Antiquarian Collection annexed thereto, State of New York in Senate Document 189. Comstock and Cassiday Printers, Albany, p. $50-60$.

HYDE, J. E. 1953. Mississippian formations of central and southern Ohio. Ohio Geological Survey Bulletin 51, 355 p.

JAeKel, O. 1918. Phylogenie und System der Pelmatozoen. Paläontologische Zeitschrift, 3(1):1-128.

Kammer, T. W. 2008. Paedomorphosis as an adaptive response in pinnulate cladid crinoids from the Burlington Limestone (Osagean, Mississippian) of the Mississippi Valley, p. 176-195. In W. I. Ausich and G. D. Webster (eds.), Echinoderm Paleobiology. Indiana University Press, Bloomington.

KAMMER, T. W. AND W. I. AusICH. 1987. Aerosol suspension feeding and current velocities: distributional controls for late Osagean crinoids. Paleobiology, 13:379-395.

KAMMER, T. W. AND W. I. Ausich. 1992. Advanced cladid crinoids from the Middle Mississippian of the east-central United States: primitivegrade calyces. Journal of Paleontology, 66:461-480.

Kammer, T. W. AND W. I. Ausich. 1993. Advanced cladid crinoids from the Middle Mississippian of the east-central United States: intermediate-grade calyces. Journal of Paleontology, 67:614-639. 
Kammer, T. W. And W. I. Ausich. 1996. Primitive cladid crinoids from upper Osagean-lower Meramecian (Mississippian) rocks of east-central United States. Journal of Paleontology, 70:835-866.

Kammer, T. W. AND W. I. Ausich. 2006. The "Age of Crinoids": a Mississippian biodiversity spike coincident with widespread carbonate ramps. Palaios, 21, 238-248.

Kammer, T. W. AND F. J. Gahn. 2003. Primitive cladid crinoids from the early Osagean Burlington Limestone and the phylogenetics of Mississippian species of Cyathocrinites. Journal of Paleontology, 77:121-138.

Kammer, T. W. AND D. L. Matchen. 2008. Evidence for eustasy at the Kinderhookian-Osagean (Mississippian) boundary in the United States: response to late Tournaisian glaciation? p. 261-274. In C. R. Fielding, T. D. Frank, and J. L. Isbell (eds.), Resolving the Late Paleozoic Ice Age in Time and Space. Geological Society of America Special Paper 441

Kammer, T. W., T. K. Baumiller, And W. I. Ausich. 1998. Evolutionary significance of differential species longevity in OsageanMeramecian (Mississippian) crinoid clades. Paleobiology, 24:155-176.

Kesling, R. V. AND D. Levasseur. 1971. Strataster ohioensis, a new Early Mississippian brittle-star, and the paleoecology of its community. Contributions from the Museum of Paleontology, the University of Michigan, 23(20):305-341.

KIRK, E. 1938. Five new genera of Carboniferous Crinoidea Inadunata. Journal of the Washington Academy of Science, 28:158-172.

KIRK, E. 1940. Seven new genera of Carboniferous Crinoidea Inadunata. Journal of the Washington Academy of Science, 30:321-334.

KIRK, E. 1941. Four new genera of Carboniferous Crinoidea Inadunata. Journal of Paleontology, 16:382-386.

KIRK, E. 1942. Rhopocrinus, a new fossil inadunate crinoid genus. Proceedings of the U.S. National Museum, 92(3144): 151-155.

KIRK, E. 1944. Aphelecrinus, a new inadunate crinoid genus from the Upper Mississippian. American Journal of Science, 242:190-203

KIRK, E. 1947. Three new genera of inadunate crinoids from the Lower Mississippian. American Journal of Science, 245:287-303.

Kullman J., D. Korn, AND D. Weyer. 1990. Ammonoid zonation of the Lower Carboniferous Subsystem. Courier Forschung-Institute Seckenberg, 130:127-131

LAHOLA, I. 1974. Mississippian conodonts from the Strongsville Member of the Cuyahoga Formation in northeastern Ohio. Master's thesis, Kent State University, Ohio, $74 \mathrm{p}$.

LANE, N. G. AND R. M. Howell. 1986. Unusual crinoids from the Ramp Creek Formation (Mississippian), Indian Creek, Montgomery County, Indiana. Journal of Paleontology, 60:898-903.

Lane, N. G., J. A. Waters, and C. G. Maples. 1997. Echinoderm faunas of the Hongguleleng Formation, Late Devonian (Famennian), Xinjiang-Uygur Autonomous Region, People's Republic of China. Journal of Paleontology Memoir, 47, $43 \mathrm{p}$.

LAUDON, L. R. 1933. The stratigraphy and paleontology of the Gilmore City Formation of Iowa. University of Iowa Studies, 15(2):74 p.

LAUDON, L. R. AND B. H. BEANE. 1937. The crinoid fauna of the Hampton Formation at LeGrand, Iowa. University of Iowa Studies, $17: 227-272$

LAudon, L. R. AND J. L. Severson. 1953. New crinoid fauna, Mississippian, Lodgepole Formation, Montana. Journal of Paleontology, 27:505-536.

Laudon, L. R., J. M. Parks, And A. C. Spreng. 1952. Mississippian crinoid fauna from the Banff Formation Sunwapta Pass, Alberta. Journal of Paleontology, 26:544-575.

Lee, K., W. I. Ausich, And T. W. Kammer. 2005. Crinoids from the Nada Member of the Borden Formation (Lower Mississippian) in eastern Kentucky. Journal of Paleontology, 79:337-355.

MATChEN, D. L. AND T. W. KAMMER. 2006. Incised valley fill interpretation for Mississippian Black Hand Sandstone, Appalachian basin, USA: implications for glacial eustasy at Kinderhookian-Osagean (Tn2-Tn3) boundary. Sedimentary Geology, 191:89-113.

McIntosh, G. C. 1983. Review of the Devonian cladid inadunate crinoids: Suborder Dendrocrinina. Ph.D. dissertation, University of Michigan, $521 \mathrm{p}$.

McInTOSH, G. C. 2001. Devonian cladid crinoids: families Glossocrinidae Goldring, 1923, and Rutkowskicrinidae new family. Journal of Paleontology, 75:783-807.

MeEk F. B. AND A. H. Worthen. 1860. Descriptions of new species of crinoidea and echinoidea from the Carboniferous rocks of Illinois, and other western states. Proceedings of the Academy of Natural Sciences of Philadelphia, 12:379-397.

Meek, F. B. And A. H. Worthen. 1869. Descriptions of new Carboniferous fossils from the western states. Proceedings of the Academy of Natural Sciences of Philadelphia, 21:137-172.
Miller, S. A. AND W. F. E. GuRley. 1890. Description of some new genera and species of Echinodermata from the Coal Measures and Subcarboniferous rocks of Indiana, Missouri, and Iowa. Journal Cincinnati Society of Natural History, 13:1-25.

Miller, S. A. AND W. F. E. GuRLEY. 1895. New and interesting species of Palaeozoic fossils. Illinois State Museum Bulletin, 7, $89 \mathrm{p}$.

Miller, S. A. AND W. F. E. GuRley. 1896. New species of crinoids from Illinois and other states. Illinois State Museum Bulletin, 9, $66 \mathrm{p}$

MilleR, J. S. 1821. A Natural History of the Crinoidea or Lily-Shaped Animals, with Observations on the Genera Asteria, Euryale, Comatula and Marsupites. Bryan, Bristol, $150 \mathrm{p}$.

MilleR, S. A. 1880. Description of two new species from the Niagara group and five from the Keokuk group. Journal of the Cincinnati Society of Natural History, 2(4):254-259.

Miller, S. A. 1889. North American Geology and Paleontology. Western Methodist Book Concern; Cincinnati, Ohio, 664 p.

MoORE, R. C. AND L. R. LAUdON. 1943. Evolution and classification of Paleozoic crinoids. Geological Society of America Special Paper, 46, $151 \mathrm{p}$.

Moore, R. C. AND L. R. LAUdon. 1944. Class Crinoidea, (eds.), p. 137209. In H. W. Shimer and R. R. Shrock, Index fossils of North America. John Wiley and Sons, Inc., New York.

Moore, R. C., N. G. LANe, AND H. L. Strimple. 1978. Order Cladida, p. T578-T759. In R. C. Moore and C. Teichert (eds.), Treatise on Invertebrate Paleontology, Part T, Echinodermata 2(2). Geological Society of America and University of Kansas Press, Boulder and Lawrence.

Owen, D. D. AND B. F. Shumard. 1850. Descriptions of fifteen new species of Crinoidea from the Subcarboniferous limestone of Iowa. Journal of the Philadelphia Academy of Natural Sciences, Series 2, 2(1): $57-70$.

PAshin, J. C. AND F. R. ETtensohn. 1995. Reevaluation of the BedfordBerea Sequence in Ohio and Adjacent States: Forced Regression in a Foreland Basin. Geological Society of America Special Paper 298, 68 p.

Peck, R. E. AND I. A. Keyte. 1938. The Crinoidea of the Chouteau Limestone, p. 70-108. In E. B. Branson (ed.), Stratigraphy and paleontology of the Lower Mississippian of Missouri, Pt. 2, Missouri University Studies, 13(4).

RodrigueZ, J. 1961. Chapter 3, Paleontology, p. 44-88. In S. I. Root, J. Rodriguez, and J. L. Forsyth, (eds), Geology of Knox County, Ohio Division of Geological Survey, Bulletin 59.

RoESER, E. W. 1986. A Lower Mississippian (Kinderhookian-Osagean) crinoid fauna from the Cuyahoga Formation of northeastern Ohio (M.S. thesis). Cincinnati, University of Cincinnati, $322 \mathrm{p}$.

Sallan, L. C., T. W. Kammer, W. I. Ausich, and L. A. Cook. 2011 Persistent-predator prey dynamics revealed by mass extinction. PNAS, Proceedings of the National Academy of Sciences, 108:8335-8338.

SPRINGER, F. 1911. Some new American fossil crinoids. Harvard College, Museum of Comparative Zoology, Memoir 25:117-161.

SPRINGER, F. 1926. Unusual forms of fossil crinoids. Proceedings of the U.S. National Museum, 67(9), 137 p.

STRIMPLe, H. L. 1967. Aphelecrinidae, a new family of inadunate crinoids. Okalahoma Geology Notes, 28:33-36.

SzMUC, E. J. 1957. Stratigraphy and paleontology of the Cuyahoga Formation of northern Ohio. Ph.D. dissertation, The Ohio State University, Columbus, $623 \mathrm{p}$.

SzMUC, E. J. 1970. Mississippian, p. 23-67. In P. O. Banks, and R. H. Feldmann (eds), Guide to the geology of northeastern Ohio. Northern Ohio Geological Society.

ThOMPSON, T. L., N. S. Ford, AND W. C. SweEt. 1971. Conodonts from the Rushville Formation (Mississippian) of Ohio. Journal of Paleontology, 45:704-712.

UBAGHS, G. 1978. Skeletal morphology of fossil crinoids, p. T58-T216. In R. C. Moore and K. Teichert (eds.), Treatise on Invertebrate Paleontology, Echinodermata, Pt. T(2). Geological Society of America and University of Kansas Press, Boulder and Lawrence.

VAN SANT, J. F. AND N. G. LANE. 1964. Crawfordsville crinoid studies. University of Kansas Paleontological Contributions, Article 7, $136 \mathrm{p}$.

WachSmuth, C. AND F. SPRINGer. 1880. Revision of the Palaeocrinoidae. Proceedings of the Academy of Natural Sciences of Philadelphia for 1879 , p. 226-378.

WachSmUth, C. AND F. SPRINGer. 1885. Revision of the Palaeocrinoidea, Pt. 3, Sec. 1. Proceedings of the Academy of Natural Sciences of Philadelphia for 1885:223-364 (1-139).

Wachsmuth, C. AND F. SPRINGER. 1886. Revision of the Palaeocrinoidae, Pt. 3, Sec. 2, Discussion of the classification and relations of the brachiate crinoids, and conclusion of the generic descriptions. Proceedings of the Academy of Natural Sciences of Philadelphia for 1885:64 $226(140-302)$ 
WeBster, G. D. 2003. Bibliography and Index of Paleozoic Crinoids, Coronates, and Hemistreptocrinids 1758-1999. Geological Society of America, Special Paper 363.

White, C. A. 1862. Description of new species of fossils from the Devonian and Carboniferous rocks of the Mississippi Valley. Boston Society of Natural History Journal, 9:8-33.

White, C. A. 1863. Observations on the summit structure of Pentremites, the structure and arrangement of certain parts of crinoids, and descriptions of new species from the Carboniferous rocks of Burlington, Iowa. Boston Society of Natural History Journal, 7:481-506.
Worthen, A. H. 1875. Descriptions of invertebrates. Illinois Geological Survey, 6:489-532.

Worthen, A. H. 1882. Descriptions of fifty-four new species of crinoids from the lower Carboniferous limestones and Coal Measures of Illinois and Iowa. Illinois State Museum of Natural History, Bulletin, $1: 3-38$.

WORTHEN, A. H. 1883. Description of fossil invertebrates. Illinois Geological Survey, 7:269-322.

ACCEPTED 19 DECEMBER 2011

APPENDIX

Comparison of genera in Kinderhookian crinoid faunas; other faunas from Webster (2003).

\begin{tabular}{|c|c|c|c|c|c|c|c|}
\hline Genus & Meadville & Banff* & Maynes Creek & Lodgepole & Henderson Canyon & Gilmore City & Osagean** \\
\hline Abrotocrinus & & 1 & & & & & 1 \\
\hline Adiakritocrinus & & & & & 1 & & \\
\hline Aphelecrinus & 1 & & 1 & & 1 & & 1 \\
\hline $\begin{array}{l}\text { Ascetocrinus } \\
\text { Atelestocrinus }\end{array}$ & $\begin{array}{l}1 \\
1\end{array}$ & & & & & & $\begin{array}{l}1 \\
1\end{array}$ \\
\hline Blothrocrinus & & 1 & 1 & 1 & 1 & & 1 \\
\hline Bridgerocrinus & & & & 1 & 1 & & \\
\hline Culmicrinus & & & & & & 1 & 1 \\
\hline Cuyahogacrinus & 1 & & & & & & \\
\hline Cyathocrinites & 1 & 1 & 1 & 1 & 1 & & 1 \\
\hline Decadocrinus & & 1 & & & & & 1 \\
\hline Dinotocrinus & & 1 & 1 & 1 & & & 1 \\
\hline Eratocrinus & & & 1 & & & & 1 \\
\hline Gilmocrinus & & & 1 & & & 1 & 1 \\
\hline Goniocrinus & 1 & & 1 & & & 1 & 1 \\
\hline Linocrinus & 1 & 1 & & 1 & & 1 & 1 \\
\hline Logocrinus & 1 & 1 & & 1 & & & \\
\hline Pachylocrinus & 1 & & & & & & 1 \\
\hline Paracosmetocrinus & 1 & & & 1 & 1 & 1 & \\
\hline Pelecocrinus & & 1 & 1 & 1 & 1 & & 1 \\
\hline Pellecrinus & & 1 & & & & & 1 \\
\hline Ramulocrinus & & 1 & & 1 & & & \\
\hline Scytalocriuns & & & & & 1 & & 1 \\
\hline Sostronocrinus & & & & & & 1 & \\
\hline Zygiocrinus & & & & & 1 & & \\
\hline Genus Richness & 14 & 12 & 12 & 10 & 10 & 8 & 25 \\
\hline
\end{tabular}

* Banff Formation spans the late Kinderhookian-early Osagean (Carter, 1987).

** Only those Osagean genera that are also found in the Kinderhookian. 